Prepared in cooperation with the U.S. Army Corps of Engineers, Mobile District Office

Borehole Geophysical and Flowmeter Data for Eight Boreholes in the Vicinity of Jim Woodruff Lock and Dam, Lake Seminole, Jackson County, Florida

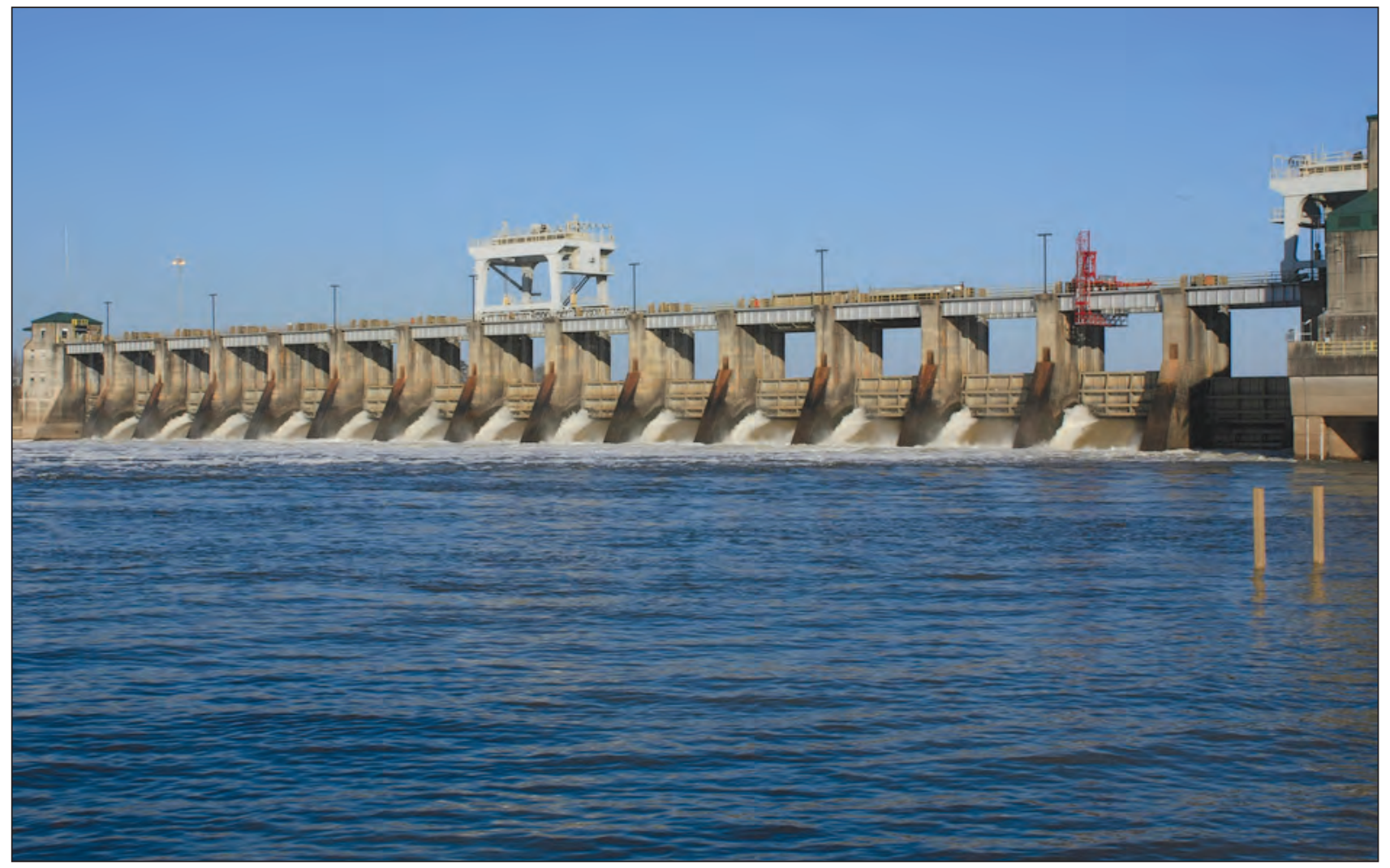

Open-File Report 2011-1254 
Cover. Jim Woodruff Lock and Dam, Lake Seminole, Jackson County, Florida. Photo by Alan M. Cressler, U.S. Geological Survey. 


\section{Borehole Geophysical and Flowmeter Data for Eight Boreholes in the Vicinity of Jim Woodruff Lock and Dam, Lake Seminole, Jackson County, Florida}

By John S. Clarke, Michael D. Hamrick, and O. Gary Holloway

Prepared in cooperation with the U.S. Army Corps of Engineers, Mobile District Office

Open-File Report 2011-1254 


\section{U.S. Department of the Interior \\ KEN SALAZAR, Secretary \\ U.S. Geological Survey \\ Marcia K. McNutt, Director}

\section{U.S. Geological Survey, Reston, Virginia: 2011}

For more information on the USGS - the Federal source for science about the Earth, its natural and living resources, natural hazards, and the environment, visit http://www.usgs.gov or call 1-888-ASK-USGS

For an overview of USGS information products, including maps, imagery, and publications, visit $h$ ttp://www.usgs.gov/pubprod

To order this and other USGS information products, visit http://store.usgs.gov

Any use of trade, product, or firm names is for descriptive purposes only and does not imply endorsement by the U.S. Government.

Although this report is in the public domain, permission must be secured from the individual copyright owners to reproduce any copyrighted materials contained within this report.

Suggested citation:

Clarke, J.S., Hamrick, M.D., and Holloway, O.G., 2011, Borehole geophysical and flowmeter data for eight boreholes in the vicinity of Jim Woodruff Lock and Dam, Lake Seminole, Jackson County, Florida: U.S. Geological Survey Open-File Report 2011-1254, 25 p. 


\section{Contents}

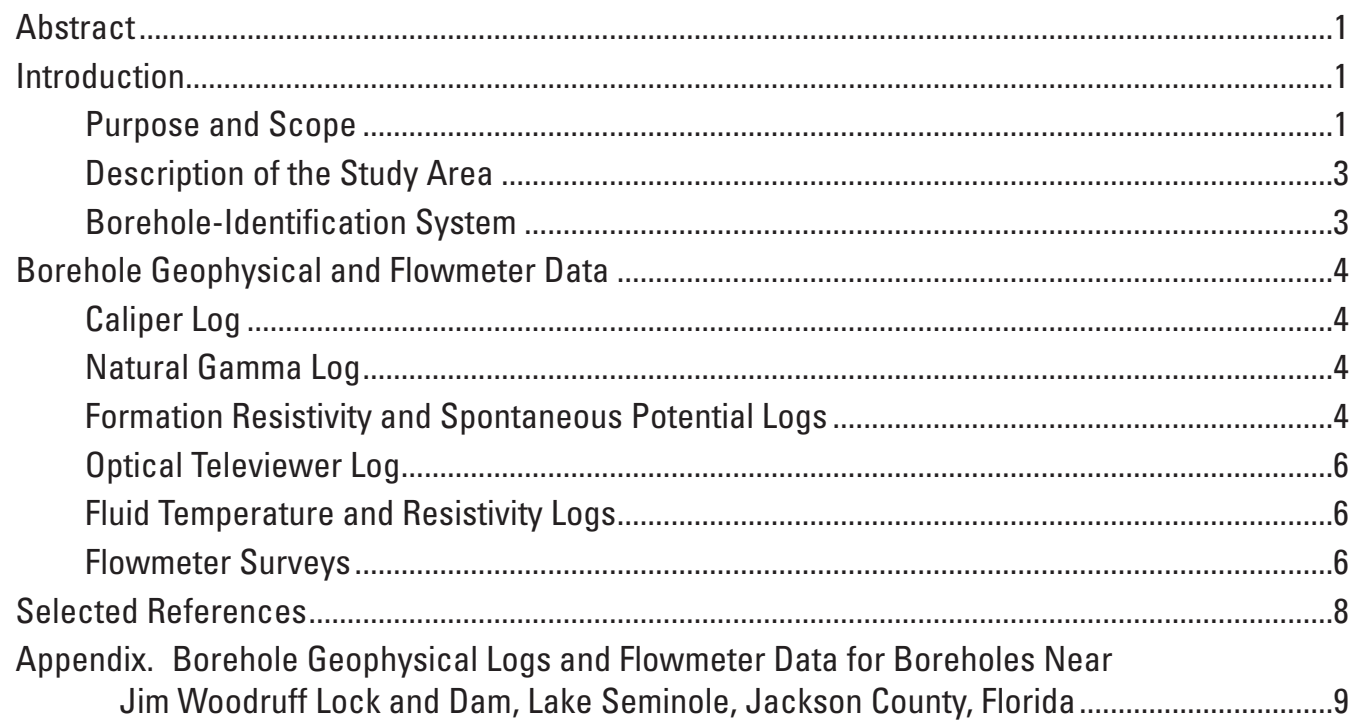

\section{Figures}

1. Location of study area and test borings near Jim Woodruff Lock and Dam, Jackson County, Florida..................................................................................................

2. Geologic and hydrologic units in the Lake Seminole study area.....................................3

3. Schematic diagrams illustrating how the strike and dip of a planar feature

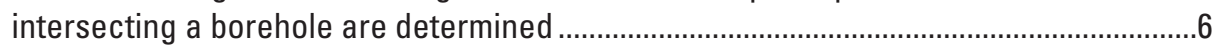

4. Calibration data for electromagnetic flow meter .......................................................

\section{Table}

1. Location, altitude, depth, and water-level information for boreholes near Jim Woodruff Lock and Dam, Lake Seminole, Jackson County, Florida

\section{Appendix Figures}

A-1 to A-8. Borehole geophysical logs and flowmeter data near Jim Woodruff Lock and Dam, Lake Seminole, Jackson County, Florida-

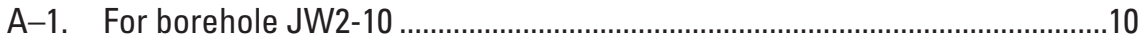

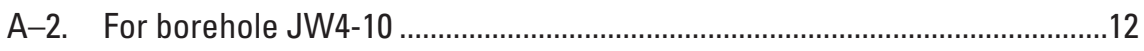

A-3. For borehole JW11 ................................................................................14

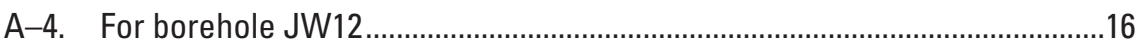

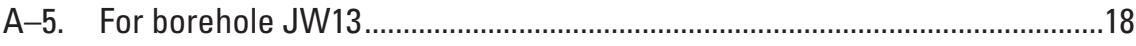

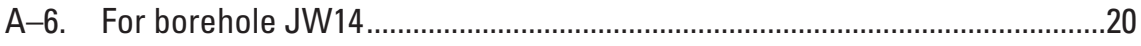

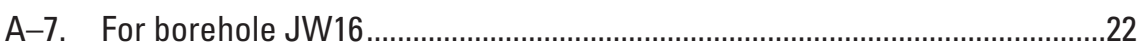

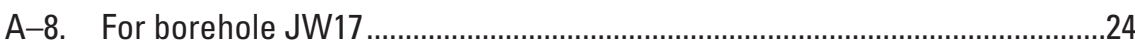




\section{Conversion Factors and Datums}

\begin{tabular}{lll}
\hline \multicolumn{1}{c}{ Multiply } & By & \multicolumn{1}{c}{ To obtain } \\
\hline inch & Length & \\
foot $(\mathrm{ft})$ & 2.54 & centimeter $(\mathrm{cm})$ \\
mile $(\mathrm{mi})$ & 0.3048 & meter $(\mathrm{m})$ \\
& 1.609 & kilometer $(\mathrm{km})$ \\
\hline square $\mathrm{mile}\left(\mathrm{mi}^{2}\right)$ & Area & square kilometer $\left(\mathrm{km}^{2}\right)$ \\
\hline & 2.590 & \\
\hline gallon per minute $(\mathrm{gal} / \mathrm{min})$ & Flow rate & liter per second $(\mathrm{L} / \mathrm{s})$ \\
\hline
\end{tabular}

Temperature in degrees Fahrenheit $\left({ }^{\circ} \mathrm{F}\right)$ may be converted to degrees Celsius $\left({ }^{\circ} \mathrm{C}\right)$ as follows:

$$
{ }^{\circ} \mathrm{C}=\left({ }^{\circ} \mathrm{F}-32\right) / 1.8
$$

Vertical coordinate information is referenced North American Vertical Datum of 1988 (NAVD 88).

Horizontal coordinate information is referenced to North American Datum of 1983 (NAD 83).

Altitude, as used in this report, refers to distance above the vertical datum.

\section{Acknowledgments}

Special thanks are extended to Patrick Murphy of the U.S. Army Corps of Engineers, Mobile District Office, Mobile, Alabama, for support during the collection of geophysical and flowmeter data.

Lester J. Williams, U.S. Geological Survey, Georgia Water Science Center, provided assistance in the interpretation of borehole structural and flowmeter data. 


\title{
Borehole Geophysical and Flowmeter Data for Eight Boreholes in the Vicinity of Jim Woodruff Lock and Dam, Lake Seminole, Jackson County, Florida
}

\author{
By John S. Clarke, Michael D. Hamrick, and O. Gary Holloway
}

\begin{abstract}
Borehole geophysical logs and flowmeter data were collected in April 2011 from eight boreholes to identify the depth and orientation of cavernous zones within the Miocene Tampa Limestone in the vicinity of Jim Woodruff Lock and Dam in Jackson County, Florida. These data are used to assess leakage near the dam. Each of the eight boreholes was terminated in limestone at depths ranging from 84 to 104 feet. Large cavernous zones were encountered in most of the borings, with several exceeding 20 -inches in diameter. The cavernous zones generally were between 1 and 5 feet in height, but a cavern in one of the borings reached a height of about 6 feet. The resistivity of limestone layers penetrated by the boreholes generally was less than $1,000 \mathrm{ohm}$-meters. Formation resistivity near the cavernous zones did not show an appreciable contrast from surrounding bedrock, probably because the bedrock is saturated, owing to its primary permeability. Measured flow rates in the eight boreholes determined using an electromagnetic flowmeter were all less than \pm 0.1 liter per second. These low flow rates suggest that vertical hydraulic gradients in the boreholes are negligible and that hydraulic head in the various cavernous zones shows only minor, if any, variation.
\end{abstract}

\section{Introduction}

Jim Woodruff Lock and Dam impounds Lake Seminole near the confluence of the Chattahoochee and Flint Rivers in southwestern Georgia and northwestern Florida (fig. 1). Dissolution of the Miocene Tampa Limestone in this area has resulted in the development of caverns that may provide a pathway for leakage of water from Lake Seminole beyond the dam. Borehole geophysical logging can provide important information on the location and orientation of fractures and caverns. Flowmeter surveys can provide information on ambient flow rates and head gradients between cavernous zones.

To identify the depth and orientation of cavernous zones and to assess borehole flow under ambient conditions, the U.S. Geological Survey (USGS), in cooperation with the U.S. Army Corps of Engineers (USACE), conducted a field testing program in April 2011. The data collected can provide important information needed for regional characterization of the Floridan aquifer system and help the USACE assess leakage near the dam.

\section{Purpose and Scope}

Data collection by the USGS included field testing at two existing and six new boreholes at the western end of the dam (fig. 1). Field testing included the collection of

- Borehole geophysical logs, including caliper; long, short, and lateral resistivity; spontaneous potential; single-point resistance; natural gamma; fluid temperature; fluid resistivity, and optical televiewer.

- Flowmeter logs under ambient (nonpumping) conditions to determine vertical flow gradients and rates of movement in the borehole. 

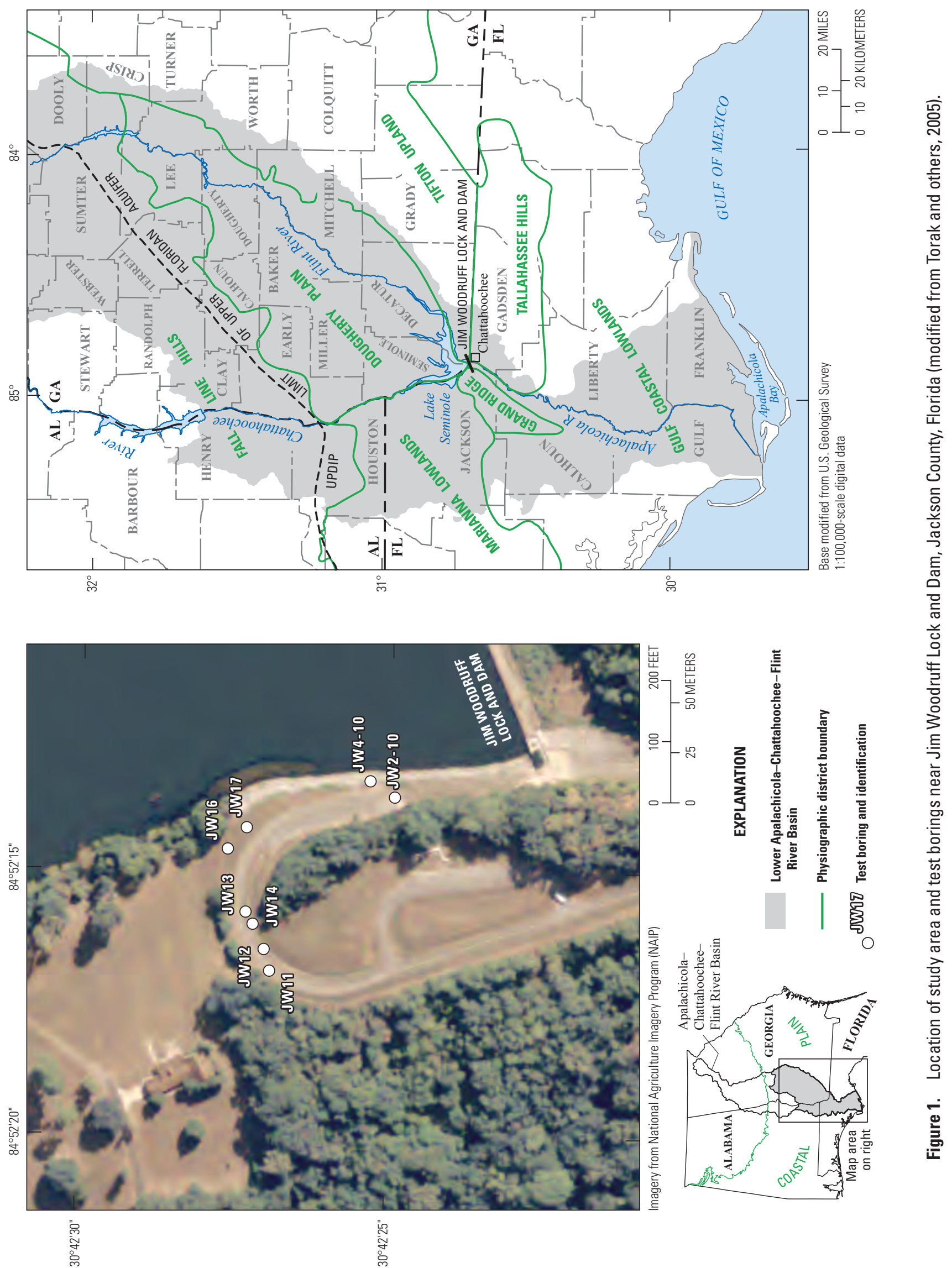


\section{Description of the Study Area}

Borehole geophysical logs and flowmeter data were collected from eight boreholes drilled along the western shore of Lake Seminole in Jackson County, Florida (fig. 1). The test borings are located about 225-560 feet (ft) upstream from Jim Woodruff Lock and Dam and about 20-310 ft from the western shoreline of Lake Seminole.

Lake Seminole covers an area of about 2,300 square miles $\left(\mathrm{mi}^{2}\right)$ within the lower Apalachicola-ChattahoocheeFlint River Basin in parts of southwestern Georgia, southeastern Alabama, and northwestern Florida (fig. 1). The study area is in the Gulf Coastal Lowlands District of the Coastal Plain Physiographic Province and is bounded to the west by the Grand Ridge region. The Gulf Coastal Lowlands District is relatively flat, with sandy, flat, seaward-sloping features shaped by wave and current activity during high sea-level stands (Torak and Painter, 2006). The Grand Ridge region consists of a series of remnant hills and sand-hill ridges as high as $250 \mathrm{ft}$ in altitude. The ridges are composed of clayey sand that overlie limestone. At the study site, a large hill to the west of Lake Seminole and the study site probably represents the Grand Ridge region.

Geologic units include, in order of ascending depth, the Eocene Lisbon Formation and Ocala Limestone; the Miocene Mariana Limestone, Suwannee Limestone, Tampa Limestone, and Hawthorne Group; and Pleistocene-Holocene terrace/undifferentiated surficial deposits (fig. 2). Each of the eight test borings was terminated within the Tampa Limestone at depths ranging from 84 to $104 \mathrm{ft}$. The Tampa Limestone consists of early Miocene sediments that overlie the Suwannee Limestone and are overlain by either clayey sands and gravels of terrace and undifferentiated deposits or the Hawthorn Group (Torak and others, 2006). The Tampa Limestone is about $170 \mathrm{ft}$ thick at the study site and consists of white, arenaceous, and argillaceous limestone, with beds of green "plastic" clay, fine sandy to clayey marl, and fine beds of scattered quartz sand interbedded within the upper $110 \mathrm{ft}$ of thickness (Moore, 1955). The foundation of Jim Woodruff Lock and Dam is emplaced in the Tampa Limestone (Torak and others, 2006).

\section{Borehole-Identification System}

In this report, boreholes are identified using a system based on USGS 71/2-minute topographic quadrangle maps.

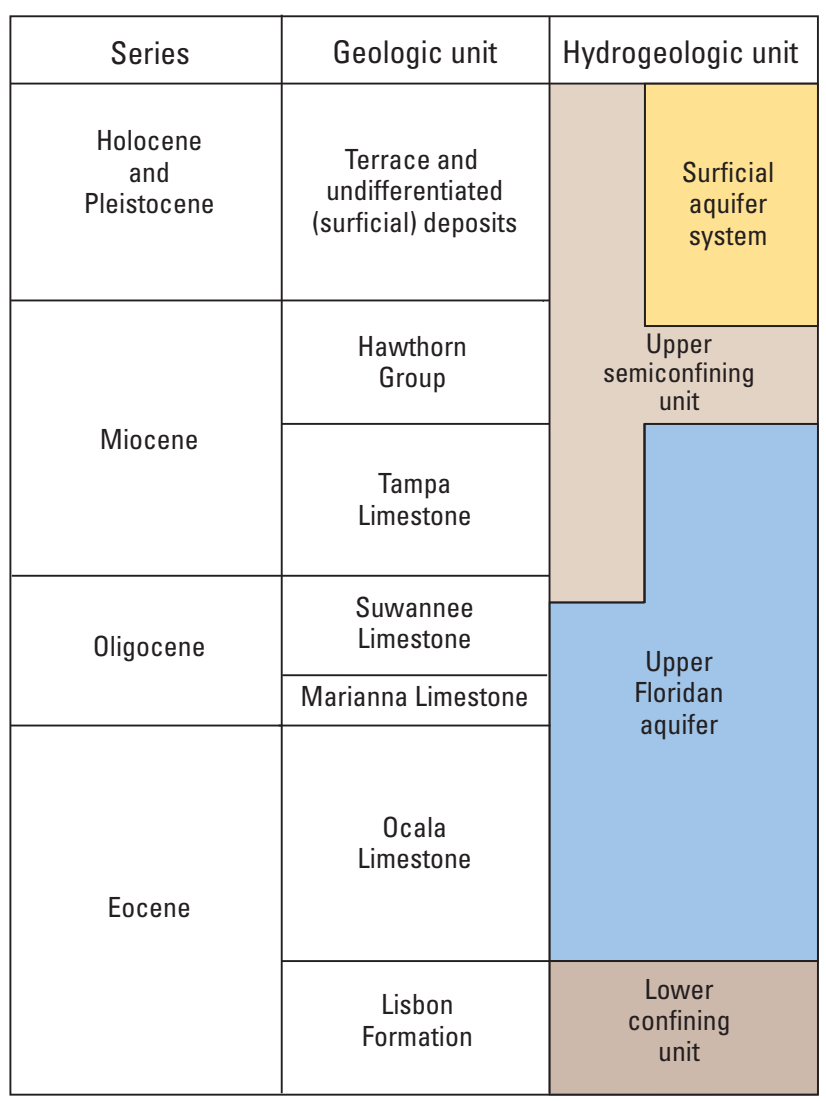

Figure 2. Geologic and hydrologic units in the Lake Seminole study area (modified from Sever, 1965a; and Torak and others, 1996).

Each topographic map in Georgia and parts of bordering States has been assigned a number and letter designation beginning at the southwestern corner of Georgia. Numbers increase eastward through 39; letters advance northward through " $Z$," then double-letter designations "AA" through "PP" are used. The letters "I," "O," "II," and "OO" are not used. Boreholes inventoried in each quadrangle are named sequentially beginning with " 1 ." Thus, the 23rd borehole inventoried in the Chattahoochee 7.5-minute quadrangle (designated 07D) in Jackson County, Florida, is designated as borehole 07D023. In addition to the USGS identification system, boreholes are identified by a USACE identifier, such as JW11. 


\section{Borehole Geophysical and Flowmeter Data}

The eight boreholes near Jim Woodruff Lock and Dam were logged using a variety of geophysical tools in waterfilled open and cased boreholes. The location, altitude, well construction, and water-level information for the boreholes is presented in table 1. Logs from each borehole include caliper, natural-gamma, resistivity (16- and 64-inch normal, single point, and lateral), spontaneous potential, fluid resistivity and temperature, and borehole optical televiewer (OTV) logs. Flowmeter surveys, using an electromagnetic (EM) flowmeter, were conducted under ambient (nonpumping) conditions in each borehole. Geophysical and flowmeter data for each of the eight boreholes are presented in the appendix, including the location and altitude, construction information, water level, and borehole deviation of each borehole. In addition, structural measurements of various features identified on OTV and caliper logs are listed as minor fracture, major fracture, bedding plane, or cavernous zone. Cavernous zones with maximum diameters exceeding 12 inches on the caliper log also are delineated for each borehole.

\section{Caliper Log}

Caliper logs were used to measure borehole diameter and identify cavernous zones in the bedrock. Changes in the borehole diameter may be related to fractures, cavernous zones, changes in lithology, borehole construction, or borehole integrity. Each of the eight boreholes initially was cored to obtain rock samples and subsequently enlarged using a 5.875-inch bit. Large cavernous zones in limestone were encountered in most of the borings, and several zones exceeded 20-inches in diameter. The cavernous zones generally were between 1 and $5 \mathrm{ft}$ in height; a maximum of about $6 \mathrm{ft}$ was measured in the 54-60 ft interval in borehole JW4-10 (fig. 1). Major cavernous zones - classified in this report as those exceeding 12 inches in borehole diameterare described in the appendix for each borehole.

\section{Natural Gamma Log}

Natural gamma logs are used to measure gamma radiation emitted by subsurface rock layers. These logs, which are reported in American Petroleum Institute Units (APIU), can be used to determine formation contacts on the basis of differences in natural gamma radiation (Keys, 1990). Typically, clays have a higher natural gamma signature than limestone or sand layers. In the study area, natural gamma logs measured natural radiation in the low 0-200 AIPU range. In general, natural gamma readings were relatively higher in the shallower clayey residuum overlying the limestone.

\section{Formation Resistivity and Spontaneous Potential Logs}

Formation resistivity is measured using single-point, long- and short-normal, and lateral resistivity logs that measure the formation's electrical resistance (reported in ohmmeters [ohm $/ \mathrm{m}]$ ). The single-point-resistance log primarily is used to identify different lithologies and waterbearing zones. The single-point tool measures the electrical resistance of a formation between an electrode in a water-filled hole and an electrode grounded at land surface. Generally, electrical resistance increases with formation grain size and decreases with borehole diameter, water-bearing fractures, and increasing dissolved-solids concentration of borehole fluids (Keys, 1990). Clay and shale have low resistance, and sand and gravel have high resistance.

The long- and short-normal and lateral resistivity logging tool applies a constant current across two electrodes while measuring the potential between two other electrodes. The short- or 16-inch normal tool measures the formation resistivity within a roughly 3 -ft spherical zone around the borehole, whereas the long- or 64-inch normal tool measures the formation resistivity within a $10-\mathrm{ft}$ spherical zone or less. The lateral tool measures the resistivity of a small volume of bedrock material in the formation without involving the material nearest to the borehole. In hard, resistive crystalline bedrock, such as limestone or dolomite, water-bearing zones may be indicated by relatively lower resistivity than the surrounding bedrock. In the study area, the resistivity of limestone layers penetrated by the boreholes generally was less than $1,000 \mathrm{ohm} / \mathrm{m}$. Formation resistivity near the cavernous zones did not show an appreciable contrast to that in the surrounding bedrock, probably because the bedrock is saturated, owing to its primary permeability.

The spontaneous-potential (SP) log records potentials or voltages developed between the borehole fluid and the surrounding rock and fluids. Spontaneous-potential logs can be used in the determination of lithology and water quality. Clays will generate one charge, and permeable formations such as sandstone will generate an opposite charge. When formation water has higher dissolved solids than the borehole fluid, clay has a positive SP response and sand has a negative SP response. 


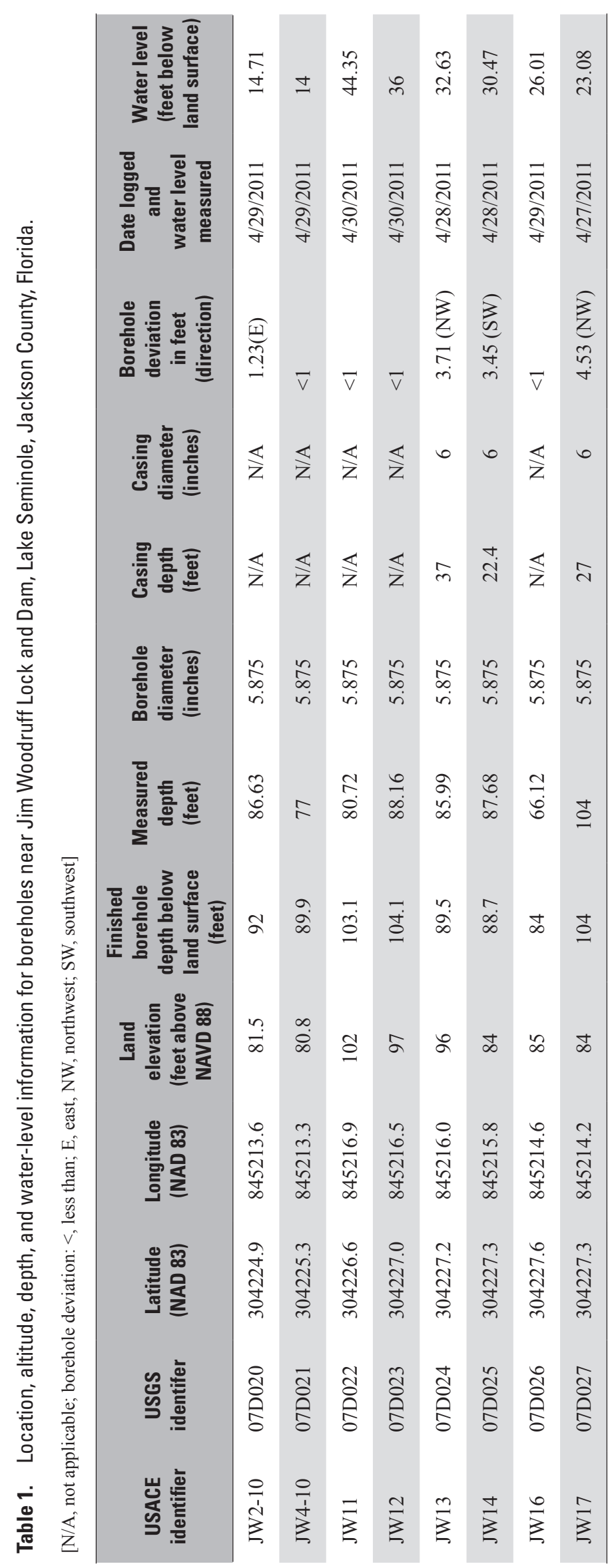




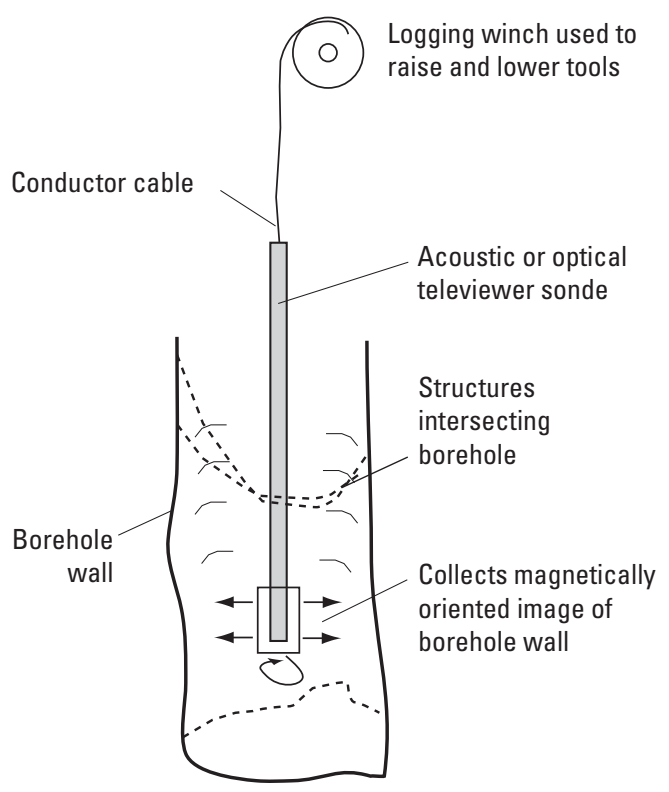

A. Diagram showing logging winch and geophysical sonde used to collect image of borehole wall.

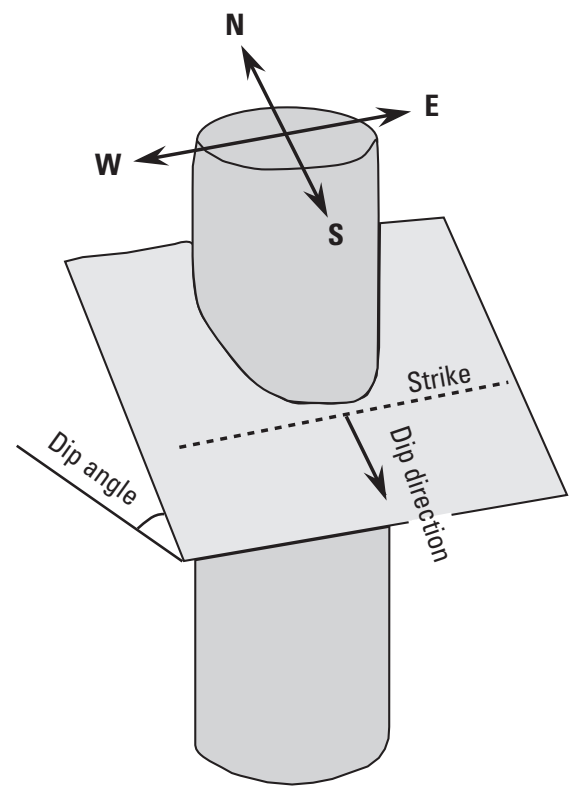

$B$. The orientation of a planar feature intersecting a borehole is described by the strike (azimuth direction a straight line would make from the intersection of an inclined plane with the horizontal) and dip angle (tilt from horizontal). In this diagram dip direction is south.

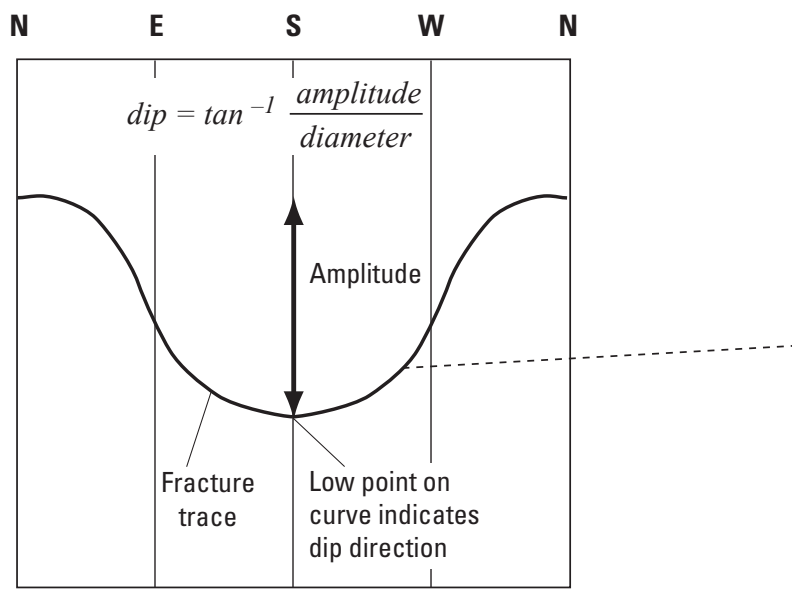

C. The trace of an intersecting plane makes a sinusoidal wave on a two-dimensional projection of the borehole wall. The amplitude of the wave and diameter of the borehole are used to calculate dip angle and dip direction.
Tadpole plot

Corrections

Borehole Magnetic deviation declination

Increasing dip angle $\longrightarrow$

$\begin{array}{lll}0 & 60\end{array}$

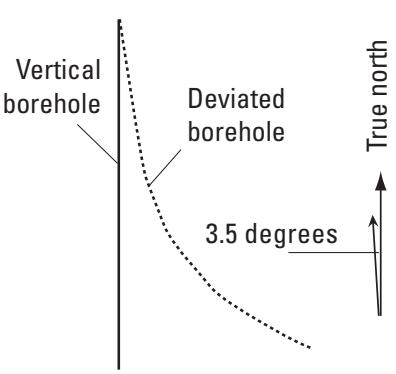

Direction: 180 degrees

Angle: 45 degrees

$D$. Tadpole plots are used to show the dip direction and dip angle. The "tail" of the tadpole points in the dip direction (similar to a plan view on a map). From left to right, the symbols are plotted with increasing dip angle. Horizontal $=0$, vertical $=90$.

Figure 3. Schematic diagrams illustrating how the strike and dip of a planar feature intersecting a borehole are determined. The calculation assumes the feature is planar (not curved). Corrections are made for borehole deviation and magnetic declination (from Williams and others, 2004). 


\section{Optical Televiewer Log}

OTV logs were used to produce a high-resolution, directionally oriented color digital image of the borehole wall (fig. $3 A$ ). Features, such as fractures, caverns, and layering (bedding), can be identified from the optical image of the borehole wall. Each borehole image is represented in two- and three-dimensions, with the center of each image representing true north. A rotation of 4 degrees west of magnetic north was applied to the data to correct for magnetic declination in the study area.

The two-dimensional OTV image includes depiction of structural features that were identifiable, including minor fractures, cavernous zones, and bedding. Depths of structural features identified from the OTV log were manually corrected to align with the caliper log data. To make the correction, the caliper log and the image logs first were plotted on the same scale, then prominent features on the OTV logs were matched to peaks on the caliper log. In this manner, the fractures, caverns, and bedding planes identified on the OTV were shifted to a common reference point - the caliper log — that is referenced to land surface. Small offsets in vertical alignment commonly occur because of different tool sizes and shifts in the reference point used for logging.

The orientation (strike and dip) of structural features was determined from the OTV log. Strike is the compass direction of a line formed by the intersection of the surface of an inclined feature with an imaginary horizontal plane (fig. $3 B$ ). Dip is the tilt or angle, perpendicular to strike, of an inclined feature measured downward from a horizontal plane. In this report, the structural orientation of features is shown in terms of the dip angle (measured from horizontal) and the dip azimuth (360-degree compass direction) using a tadpole plot (fig. 3D). Strike and dip were computed using WellCad $\odot$, a commercial log processing program from Advanced Logic Technology. When viewed in a two-dimensional projection of the borehole wall, planar-dipping features form an ellipse across the borehole, which appears as a sinusoidal wave on a two-dimensional depiction of the borehole wall (Williams and others, 2004). The lowest point on the sinusoidal wave gives the direction of the dipping plane (fig. $3 C$ ). The true strike and dip were calculated using the WellCad $\odot$ image-processing module, which corrects for borehole deviation. Adjustments for borehole deviation were minor; all of the boreholes had less than $5 \mathrm{ft}$ of deviation, and four of the eight had less than $1 \mathrm{ft}$ of deviation.

\section{Fluid Temperature and Resistivity Logs}

Fluid-temperature and fluid-resistivity logs are useful for delineating water-bearing zones and identifying vertical borehole flow between zones of differing hydraulic head. Changes in fluid temperature and resistivity may indicate inflow or outflow of water from the borehole and can be used to help identify water-bearing zones (Williams and others, 2004).
The use of fluid temperature and fluid resistivity logs at the study site was affected by the injection of polymer drilling fluids mixed with lake water into the boreholes to flush out sediment immediately before logging. This injection resulted in an unnatural borehole condition and highly variable fluid temperatures. In general, fluid resistivity decreased in deeper parts of each borehole, suggesting higher dissolved-solids concentrations. No sharp deflections indicative of an influx of formation water into the borehole were noted on either the fluid temperature or fluid resistivity logs.

\section{Flowmeter Surveys}

Flowmeter logging measures the direction and magnitude of vertical fluid flow within a borehole and can be used to identify water-producing or water-losing intervals in a borehole. Flowmeter measurements were made using an EM flowmeter at discrete locations above and below cavernous zones identified using geophysical logs. Accuracy of flowmeter measurements can be improved if a flow diverter is used with the tool to focus flow toward the detector; however, the highly irregular borehole conditions attributed to cavern formation at the study site prohibited the use of a flow diverter. It is likely, therefore, that some flow in the borehole bypassed the detector. Flow rates were calibrated for upflow, noflow, and downflow conditions using a flow chamber where flow was varied by 0.15 liter per second (L/s; fig. 4). A simple linear regression for the three flow conditions had an R-square of 0.97 , indicating a reasonable fit of metered readings to flow rates. The resulting regression equation was applied to meter readings to obtain an estimated flow rate.

Measured flow rates in the eight boreholes were all less than $\pm 0.1 \mathrm{~L} / \mathrm{s}$. These low flow rates suggest that vertical hydraulic gradients in the boreholes are negligible, and hydraulic head in the various cavernous zones shows only minor, if any, variation. As noted previously, fluid temperature logs were highly variable, reflecting the injection of drilling fluids derived from lake water. Despite this injection, the lack of flow in the borehole suggests that the highly transmissive cavernous zones readily accept injected water and that heads equilibrate quickly.

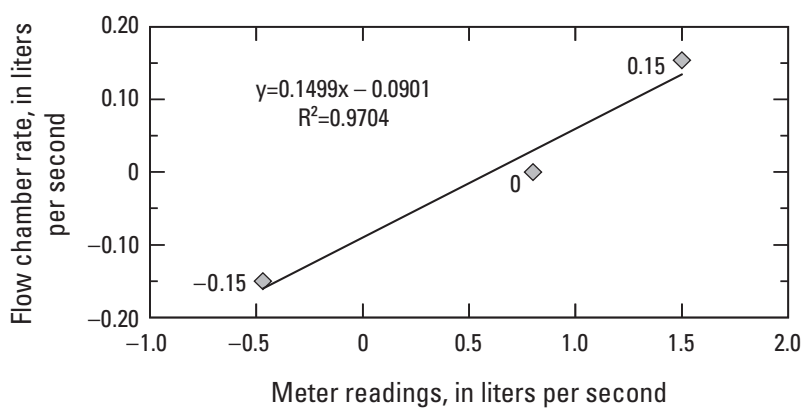

Figure 4. Calibration data for electromagnetic flow meter. 


\section{Selected References}

Keys, W.S., 1990, Borehole geophysics applied to groundwater investigations: U.S. Geological Survey Techniques of Water-Resources Investigations, book 2, chap. E2, $166 \mathrm{p}$.

Moore, W.E., 1955, Geology of Jackson County, Florida: Florida Geological Survey Bulletin 37, 101 p.

Torak, L.J., Crilley, D.M., and Painter, J.A., 2006, Physical and hydrochemical evidence of lake leakage near Jim Woodruff Lock and Dam and of ground-water inflow to Lake Seminole, and an assessment of karst features in and near the lake, southwestern Georgia and northwestern Florida: U.S. Geological Survey Scientific Investigations Report 2005-5084, 90 p. (Also available at $h t t p: / / p u b s$. usgs.gov/sir/2005/5084/.)

Torak, L.J., and Painter, J.A., 2006, Geohydrology of the Lower Apalachicola-Chattahoochee-Flint River Basin, southwestern Georgia, northwestern Florida, and southeastern Alabama: U.S. Geological Survey Scientific Investigations Report 2006-70, 73 p. (Also available at http://pubs.usgs.gov/sir/2006/5070/.)

Williams, L.J., Albertson, P.N., Tucker, D.D., and Painter, J.A., 2004, Methods and hydrogeologic data from test drilling and geophysical logging survey in the Lawrenceville, Georgia, area: U.S. Geological Survey Open-File Report 2004-1366, 38 p. (Also available at http://pubs.usgs.gov/ of/2004/1366/.) 
Appendix. Borehole Geophysical Logs and Flowmeter Data for Boreholes Near Jim Woodruff Lock and Dam, Lake Seminole, Jackson County, Florida 
Borehole identifier: JW2-10

Land-surface altitude, in feet NAVD88: 81.5

Latitude (NAD83): 304224.9

Longitude (NAD83): 0845213.6

Date logged: 4/29/2011

Borehole deviation: East 1.23 feet

\section{All depths in feet}

Depth to groundwater: 14.71

Drilled depth: 92

Measured depth: 86.6

Casing depth: None.

Casing diameter (inches): None.

Structural measurements

$\begin{array}{llll}\text { Depth } & \text { DipAzm } & \text { DipAng } & \text { Type } \\ 15.5 & 192.26 & 27.79 & \text { F, B } \\ 18.5 & 321.32 & 29.09 & \text { C } \\ 21.3 & 322.94 & 29.09 & \text { C } \\ 57.5 & 282.66 & 30.94 & \text { C }\end{array}$

Type: $\mathrm{F}$, minor fracture; $\mathrm{B}$, bedding plane; C, cavernous zone

Remarks: Bottom 35 feet of boring filled with clear polymer drillling fluid.

Major cavern zone-Maximum diameter exceeds 12 inches

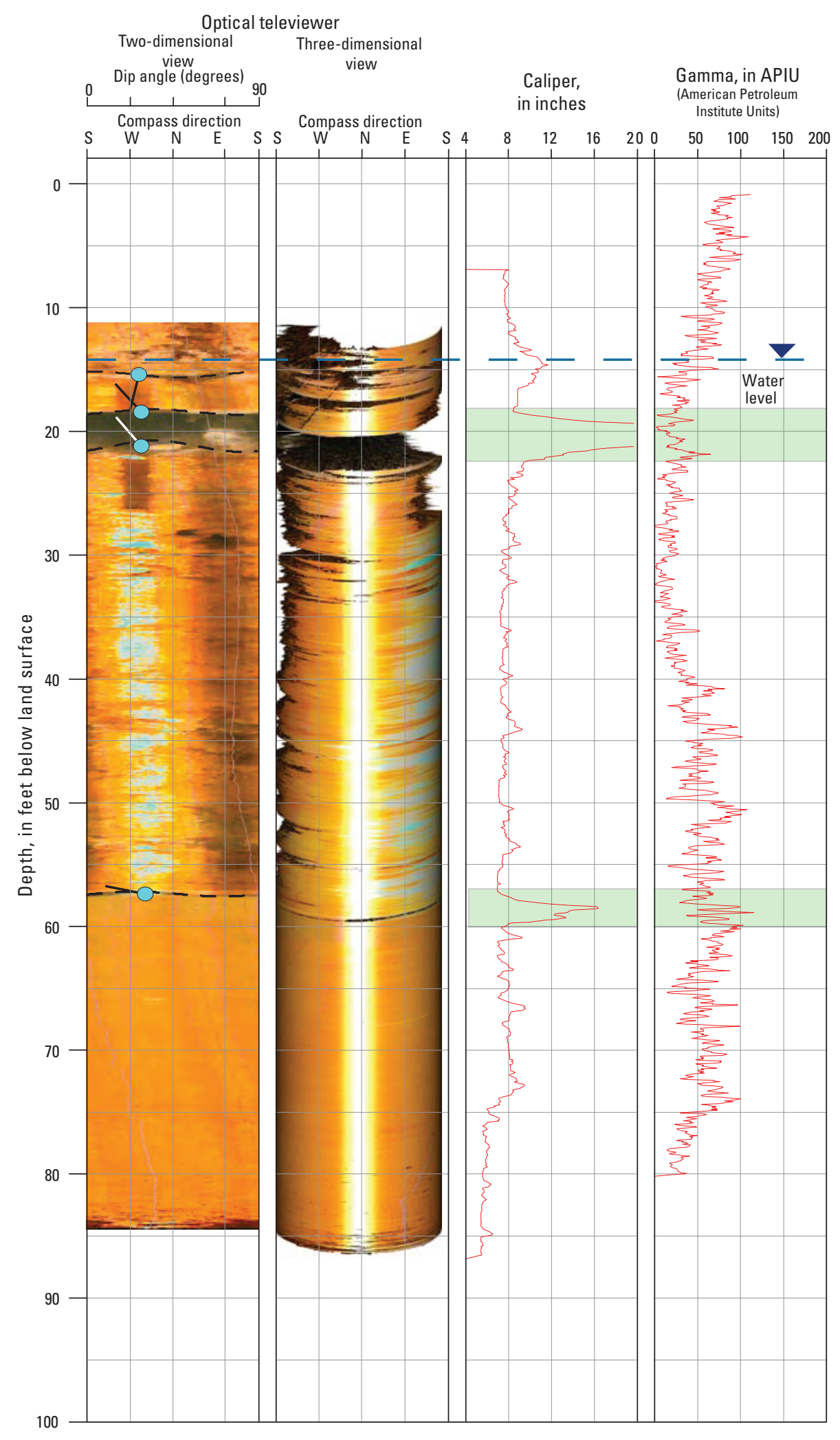

Figure A-1. Borehole geophysical logs and flowmeter data for borehole JW2-10 near Jim Woodruff Lock and Dam, Lake Seminole, Jackson County, Florida. 


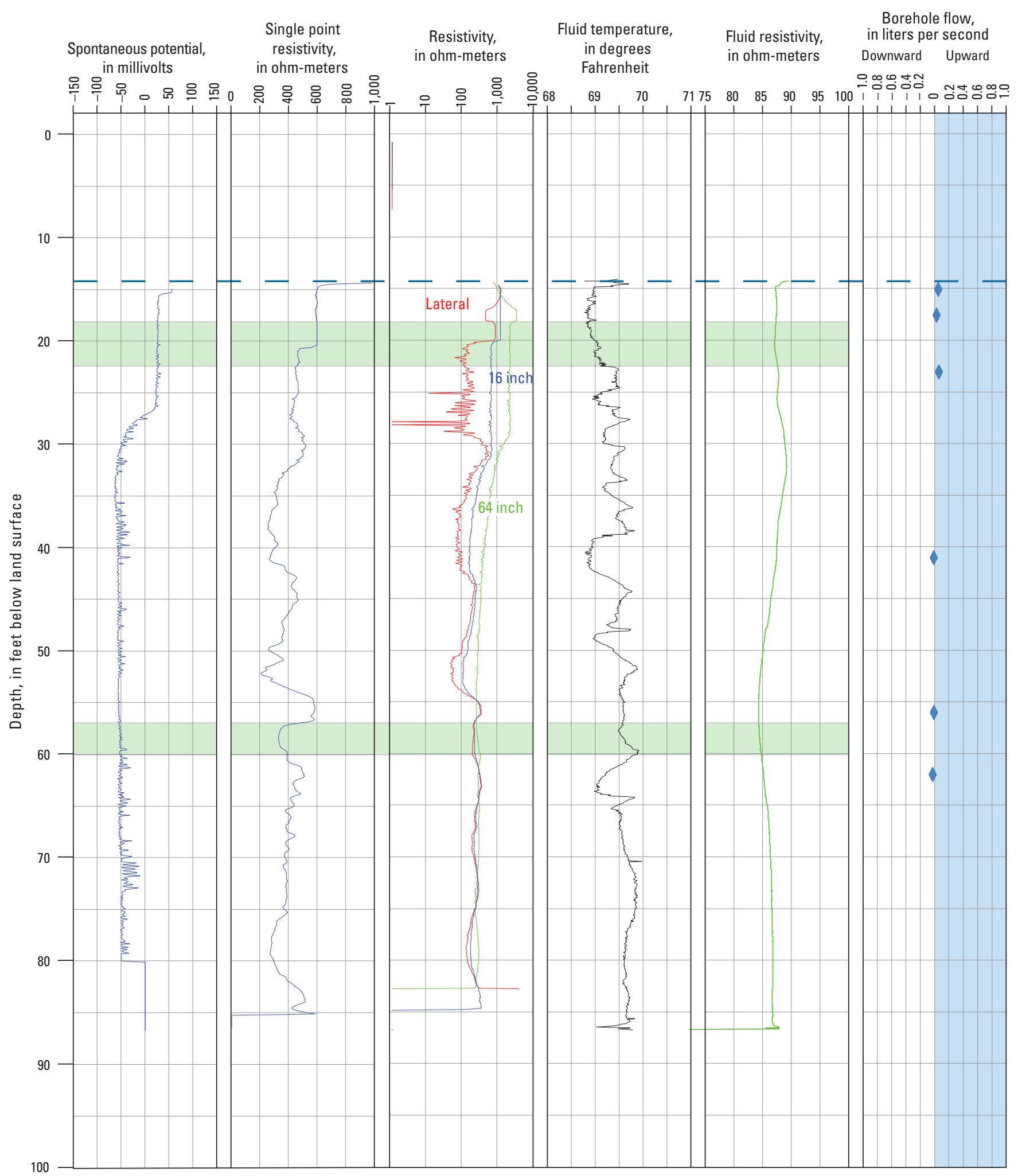

Figure A-1. Borehole geophysical logs and flowmeter data for borehole JW2-10 near Jim Woodruff Lock and Dam, Lake Seminole, Jackson County, Florida.-Continued 
Borehole identifier: JW4-10

Land-surface altitude,

in feet NAVD88: 80.8

Latitude (NAD83): 304225.3

Longitude (NAD83): 0845213.3

Date logged: $4 / 29 / 2011$

Borehole deviation: less than 1 foot

All depths in feet

Depth to groundwater: 14.0

Drilled depth: 89.9

Measured depth: 77.0

Casing depth: None.

Casing diameter (inches): None.

Structural measurements

Depth DipAzm DipAng Type

$\begin{array}{llll}18.3 & 118.45 \quad 34.87 \quad C\end{array}$

$\begin{array}{llll}36.4 & 313.84 & 35.37 \quad \mathrm{C}\end{array}$

$\begin{array}{llll}38.2 & 312.72 & 34.8 \quad \mathrm{C}\end{array}$

$\begin{array}{llll}51.7 & 46.31 & 17.93 & \text { B }\end{array}$

Type: $\mathrm{F}$, minor fracture; $\mathrm{B}$, bedding plane; $\mathrm{C}$, cavernous zone

Remarks: None.

Major cavern zone-Maximum diameter exceeds 12 inches

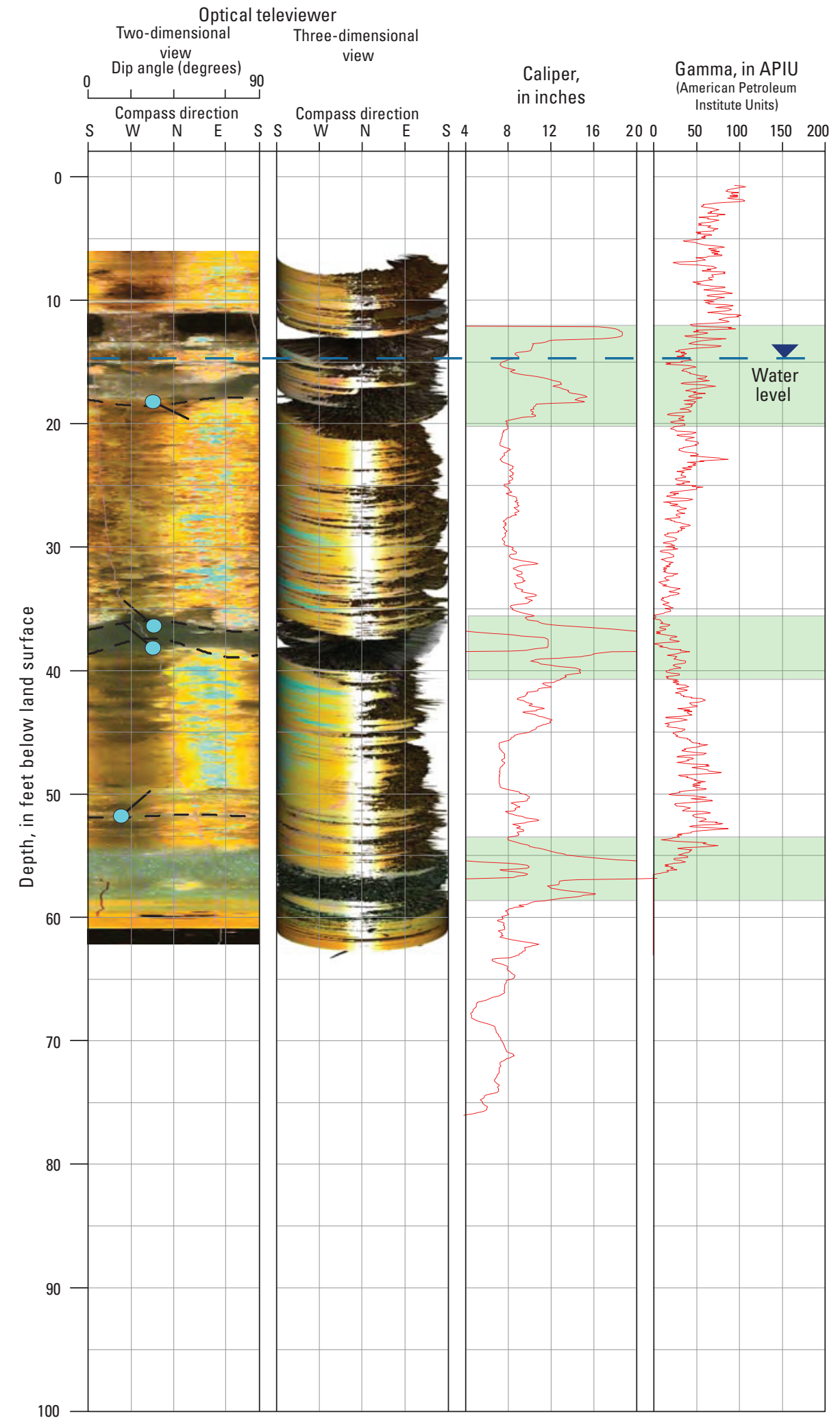

Figure A-2. Borehole geophysical logs and flowmeter data for borehole JW4-10 near Jim Woodruff Lock and Dam, Lake Seminole, Jackson County, Florida. 


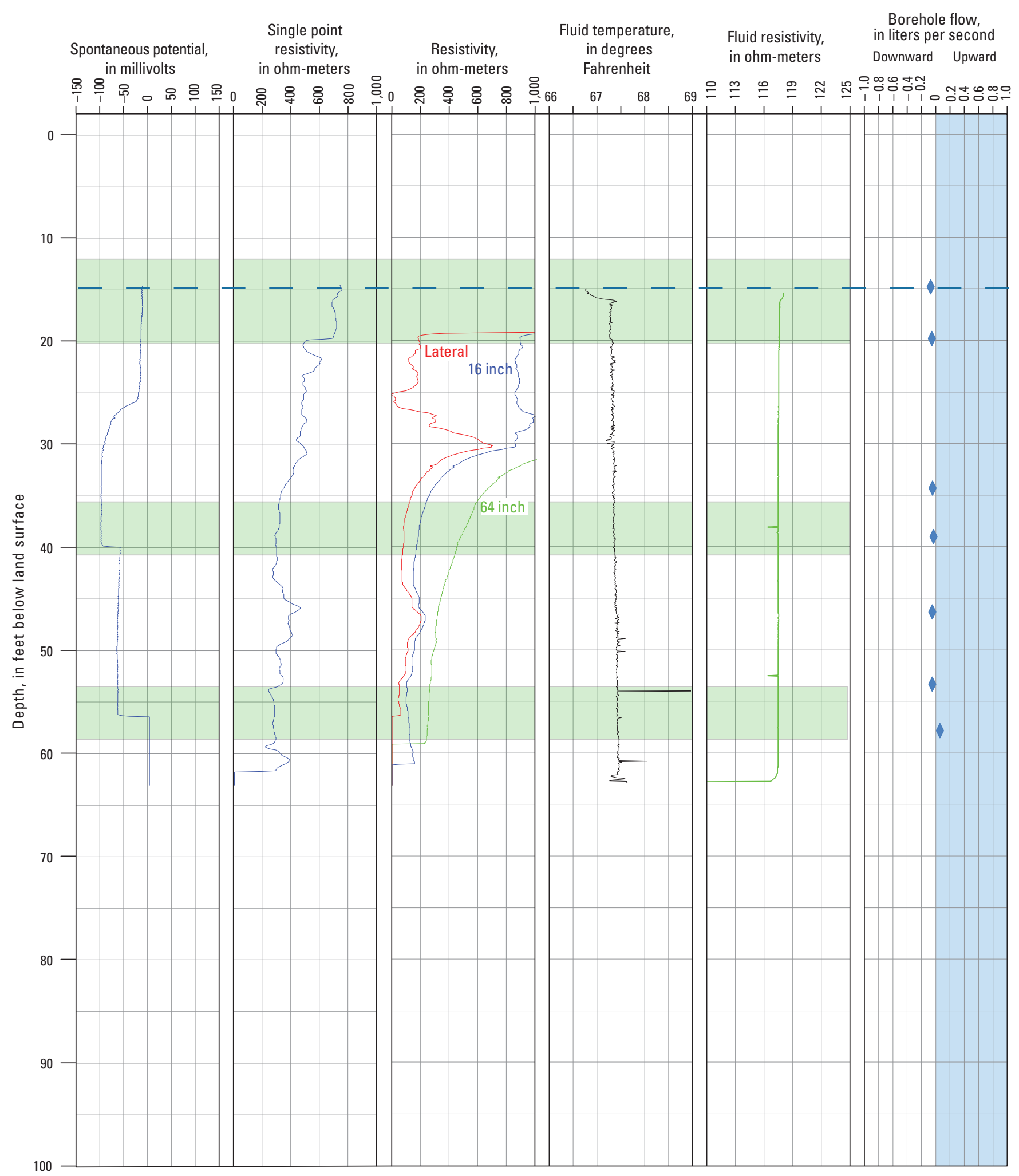

Figure A-2. Borehole geophysical logs and flowmeter data for borehole JW4-10 near Jim Woodruff Lock and Dam, Lake Seminole, Jackson County, Florida.-Continued 
Borehole identifier: JW11

Land-surface altitude,

in feet NAVD88: 102

Latitude (NAD83): 304226.9

Longitude (NAD83): 0845216.9

Date logged: 4/30/2011

Borehole deviation: less than 1 foot

All depths in feet

Depth to groundwater: 44.35

Drilled depth: 103

Measured depth: 80.7

Casing depth: None.

Casing diameter (inches): None.

Structural measurements

Depth DipAzm DipAng Type

$\begin{array}{llll}70.6 & 200.67 & 32.31 & \text { F, B }\end{array}$

Type: $F$, minor fracture; $B$, bedding plane

Remarks: 0-62 foot interval logged through drilling rods due to caving in upper part of bore hole.

Major cavern zone-Maximum diameter exceeds 12 inches

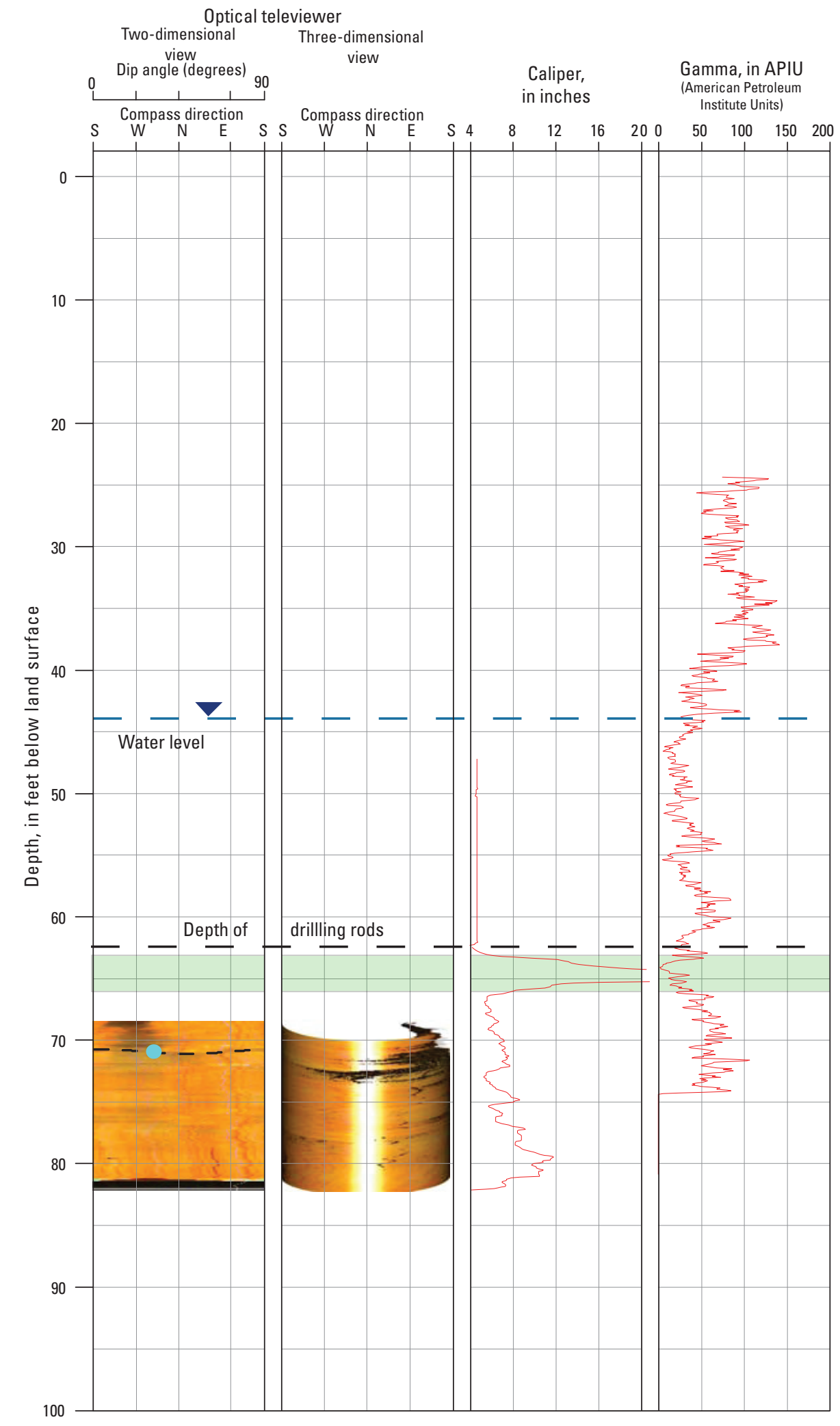

Figure A-3. Borehole geophysical logs and flowmeter data for borehole JW11 near Jim Woodruff Lock and Dam, Lake Seminole, Jackson County, Florida. 


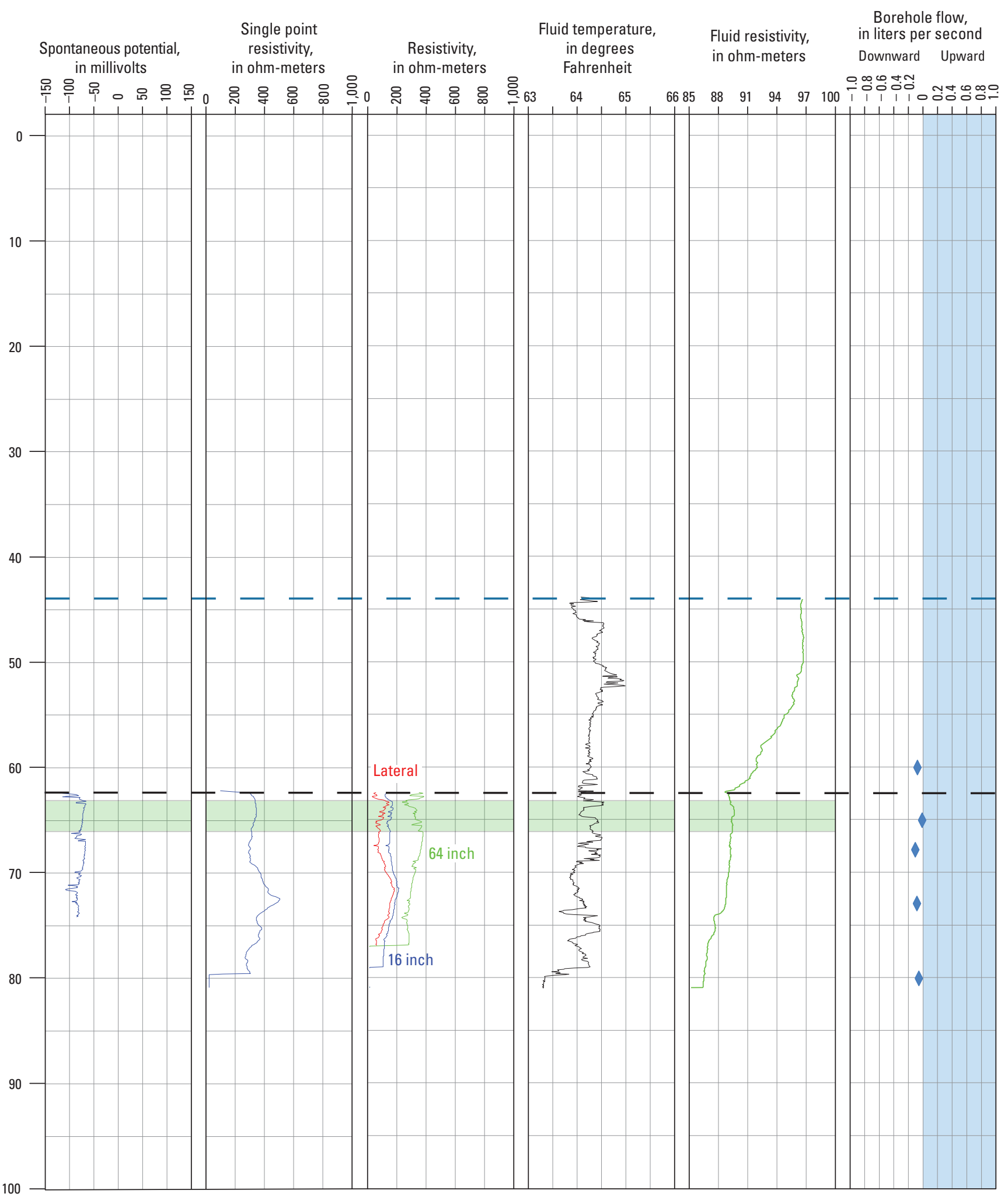

Figure A-3. Borehole geophysical logs and flowmeter data for borehole JW11 near Jim Woodruff Lock and Dam, Lake Seminole, Jackson County, Florida.-Continued 
Borehole identifier: JW12

Land-surface altitude, in feet NAVD88: 97.0

Latitude (NAD83): 304227.0

Longitude (NAD83): 0845216.5

Date logged: 4/30/2011

Borehole deviation: less than 1 foot.

All depths in feet

Depth to groundwater: 36.0

Drilled depth: 104

Measured depth: 88.2

Casing depth: None.

Casing diameter (inches): None.

Structural measurements

Depth DipAzm DipAng Type

$\begin{array}{llll}35.8 & 77.39 & 38.76 & \text { F, B }\end{array}$

Type: $\mathrm{F}$, minor fracture; $\mathrm{B}$, bedding plane

Remarks: Sediment in bottom of hole Only caliper tool could penetrate to depth of 88.2 feet. Borehole collapsed to 63.5 feet by end of logging.

Major cavern zone-Maximum diameter exceeds 12 inches

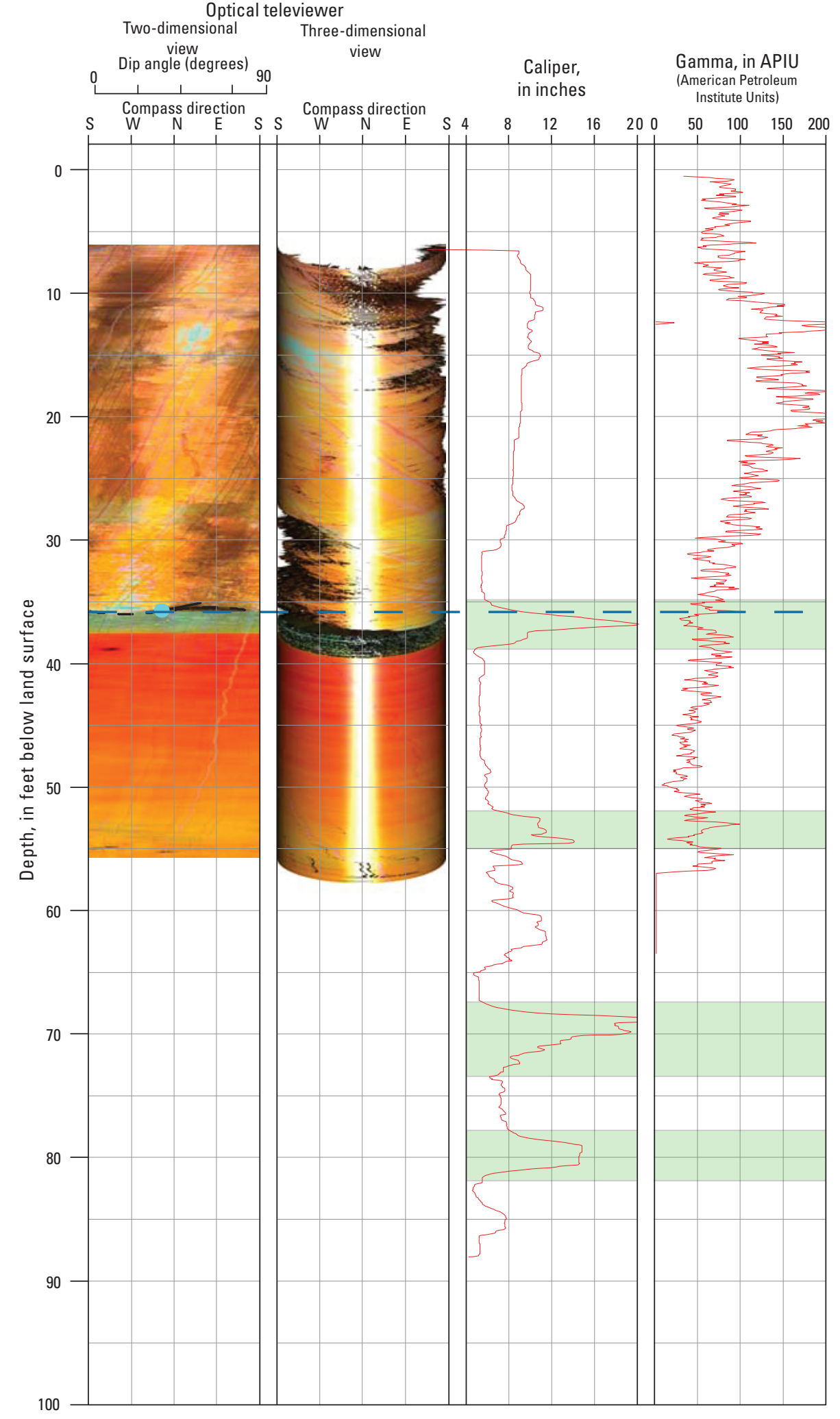

Figure A-4. Borehole geophysical logs and flowmeter data for borehole JW12 near Jim Woodruff Lock and Dam, Lake Seminole, Jackson County, Florida. 


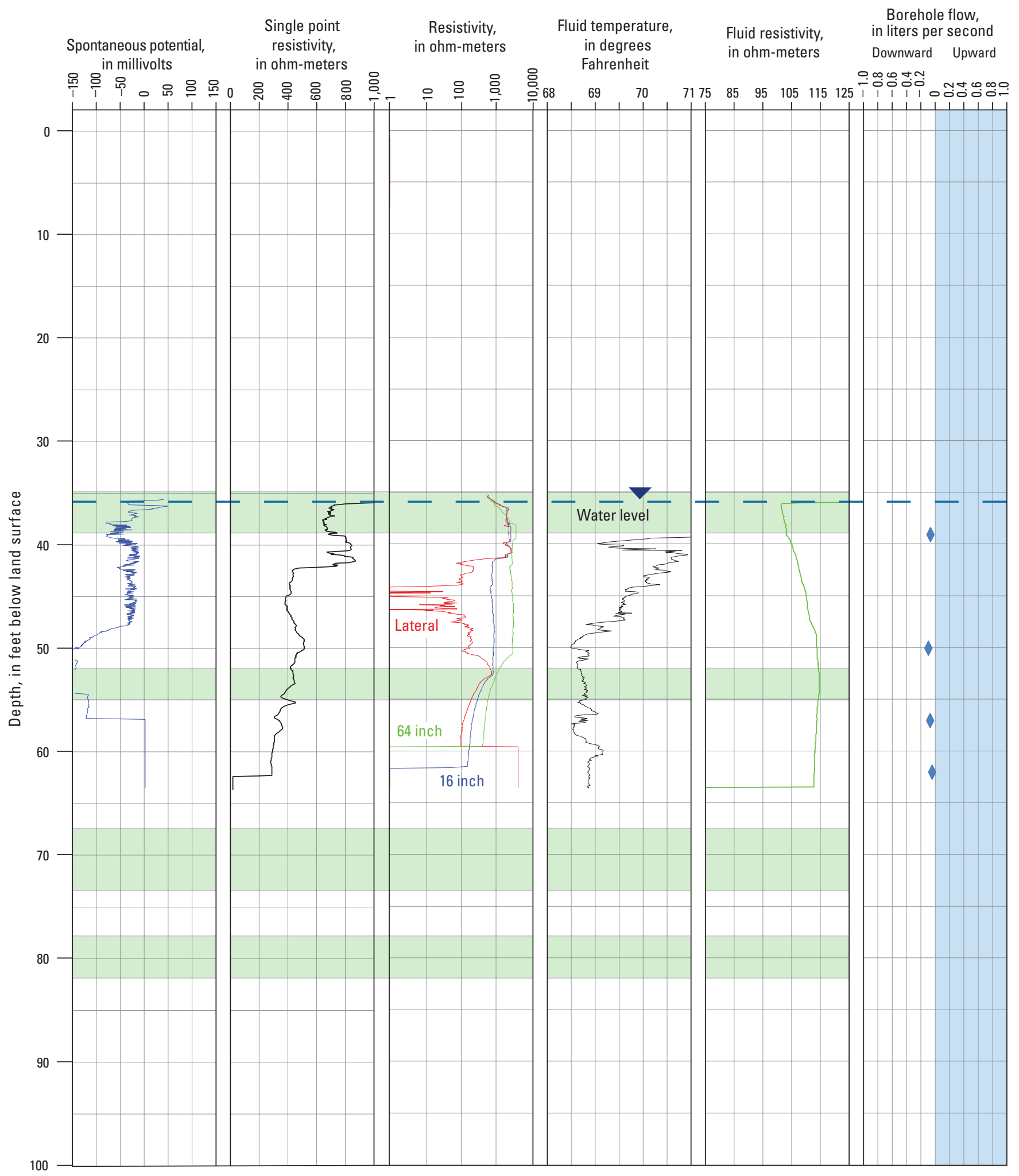

Figure A-4. Borehole geophysical logs and flowmeter data for borehole JW12 near Jim Woodruff Lock and Dam, Lake Seminole, Jackson County, Florida.-Continued 
Borehole identifier: JW13

Land-surface altitude,

in feet NAVD88: 96.0

Latitude (NAD83): 304227.2

Longitude (NAD83): 0845216.0

Date logged: 4/28/2011

Borehole deviation: Northwest 3.71 feet

All depths in feet

Depth to groundwater: 32.63

Drilled depth: 89.5

Measured depth: 86

Casing depth: 37

Casing diameter (inches): 6

Structural measurements

$\begin{array}{llll}\text { Depth } & \text { DipAzm } & \text { DipAng } & \text { Type } \\ 45.3 & 288.03 & 41.31 & \text { C } \\ 47.5 & 295.93 & 36.39 & \text { C } \\ 56.6 & 76 & 49.67 & \text { F, B } \\ 64.2 & 249.29 & 68.81 & \text { F } \\ 72.3 & 32.44 & 31 & \text { C } \\ 73.2 & 21.2 & 26.59 & \text { C }\end{array}$

Type: C, cavernous zone; $\mathrm{F}$, minor fracture; $\mathrm{B}$, bedding plane

Remarks: Borehole depth initially measured at 86 feet. By end of logging hole had collapsed to 73 feet.

Major cavern zone-Maximum diameter exceeds 12 inches

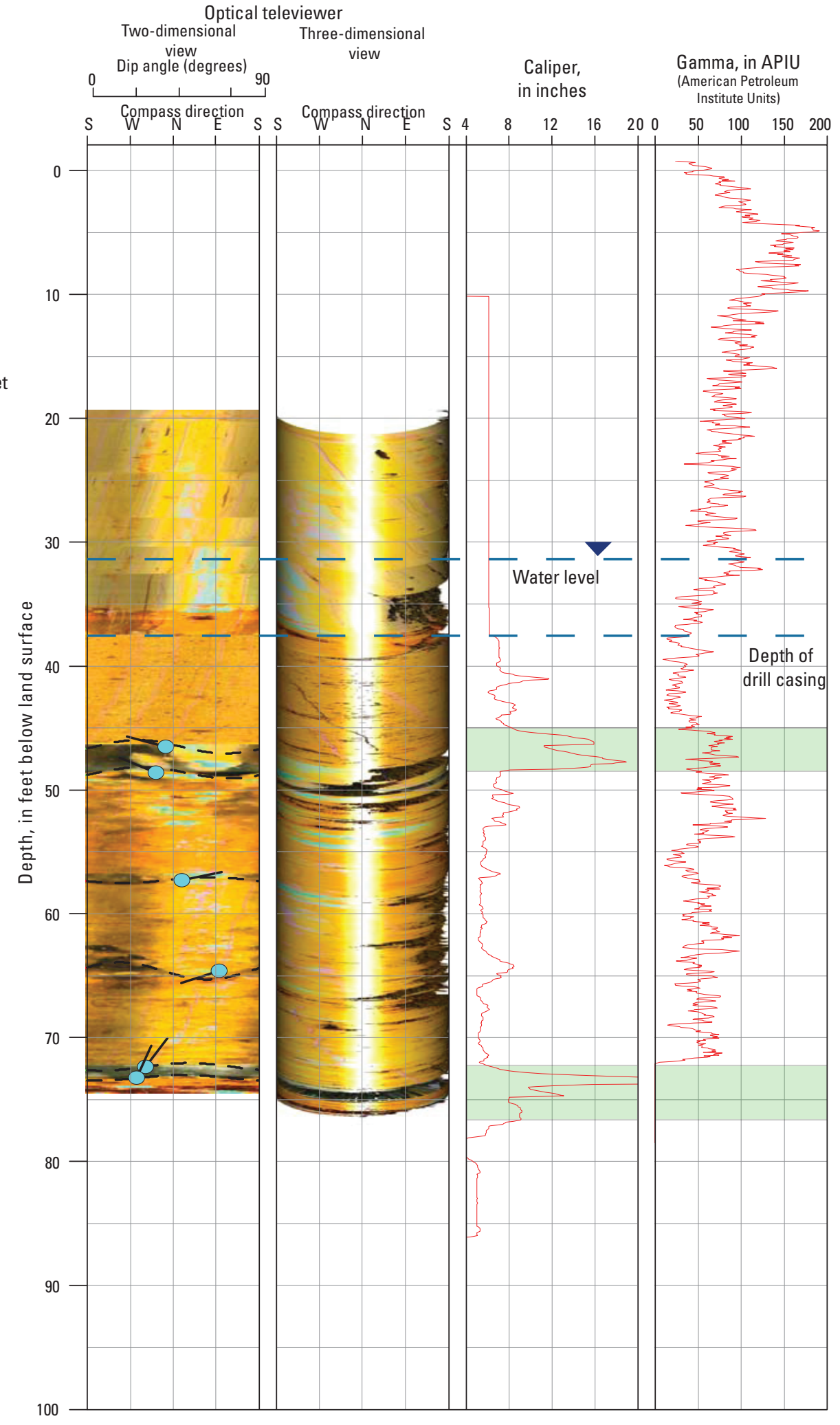

Figure A-5. Borehole geophysical logs and flowmeter data for borehole JW13 near Jim Woodruff Lock and Dam, Lake Seminole, Jackson County, Florida. 


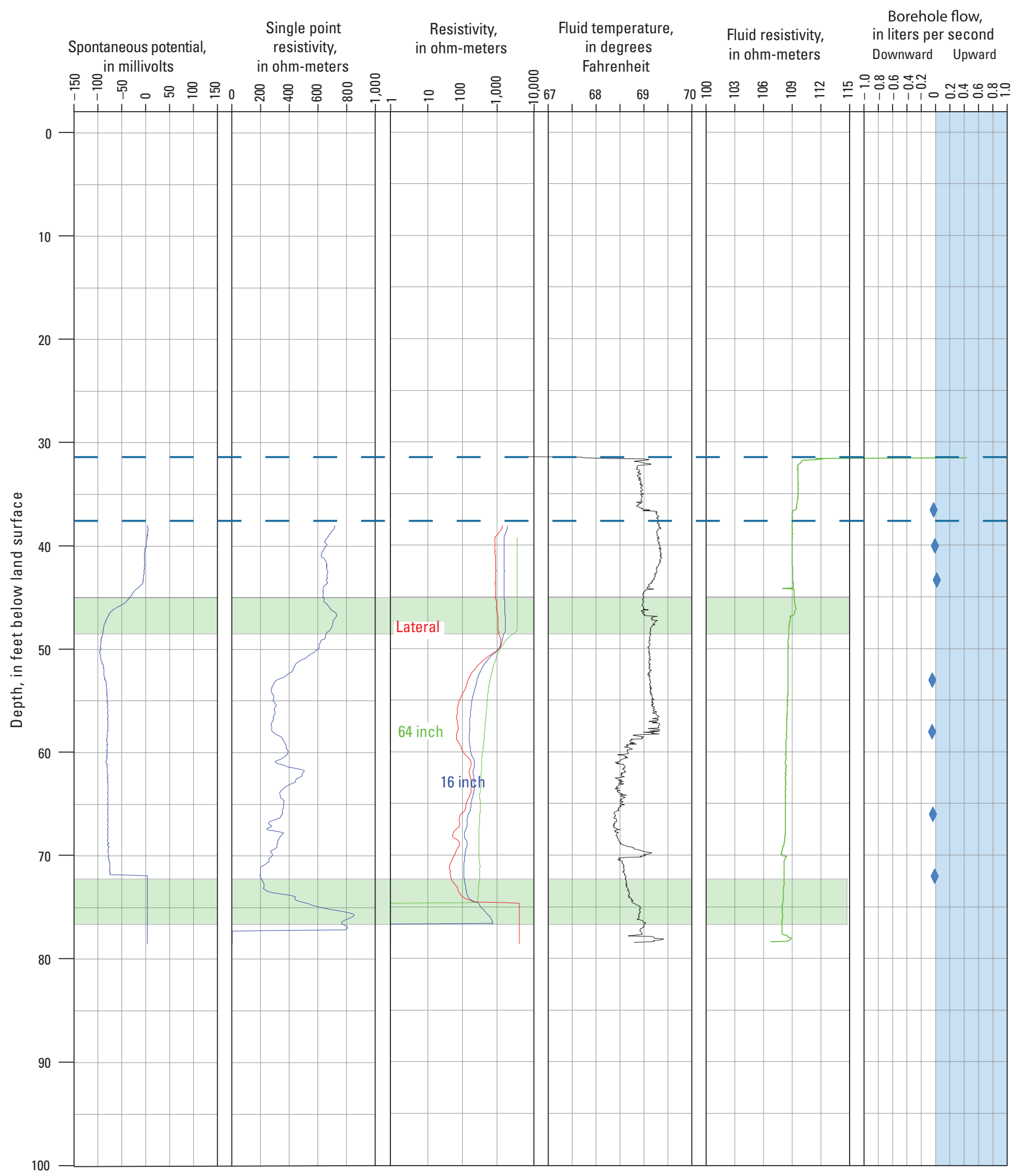

Figure A-5. Borehole geophysical logs and flowmeter data for borehole JW13 near Jim Woodruff Lock and Dam, Lake Seminole, Jackson County, Florida.-Continued 
Borehole identifier: JW14

Land-surface altitude, in feet NAVD88: 90.0

Latitude (NAD83): 304227.3

Longitude (NAD83): 0845215.8

Date logged: 4/28/2011

Borehole deviation: Southwest 3.45 feet

All depths in feet

Depth to groundwater: 30.47

Drilled depth: 88.7

Measured depth: 87.7

Casing depth: 22.4

Casing diameter (inches): 6

Structural measurements

$\begin{array}{llll}\text { Depth } & \text { DipAzm } & \text { DipAng } & \text { Type } \\ 29 & 335.9 & 59.42 & \text { F } \\ 33.2 & 309.09 & 32.09 & \text { C } \\ 34.2 & 319.13 & 32.09 & \text { C } \\ 39.8 & 231.95 & 70.01 & \text { F } \\ 41.4 & 18.2 & 53.94 & \text { F, B } \\ 46.0 & 240.15 & 52.91 & \text { F, B }\end{array}$

Type: $F$, minor fracture; $B$, bedding plane; C, cavernous zone

Remarks: Initial borehole depth measured at 87.7 feet. By end of logging had collapsed to 73.3 feet.

$$
\begin{aligned}
& \text { Major cavern zone-- } \\
& \text { Maximum diameter } \\
& \text { exceeds } 12 \text { inches }
\end{aligned}
$$

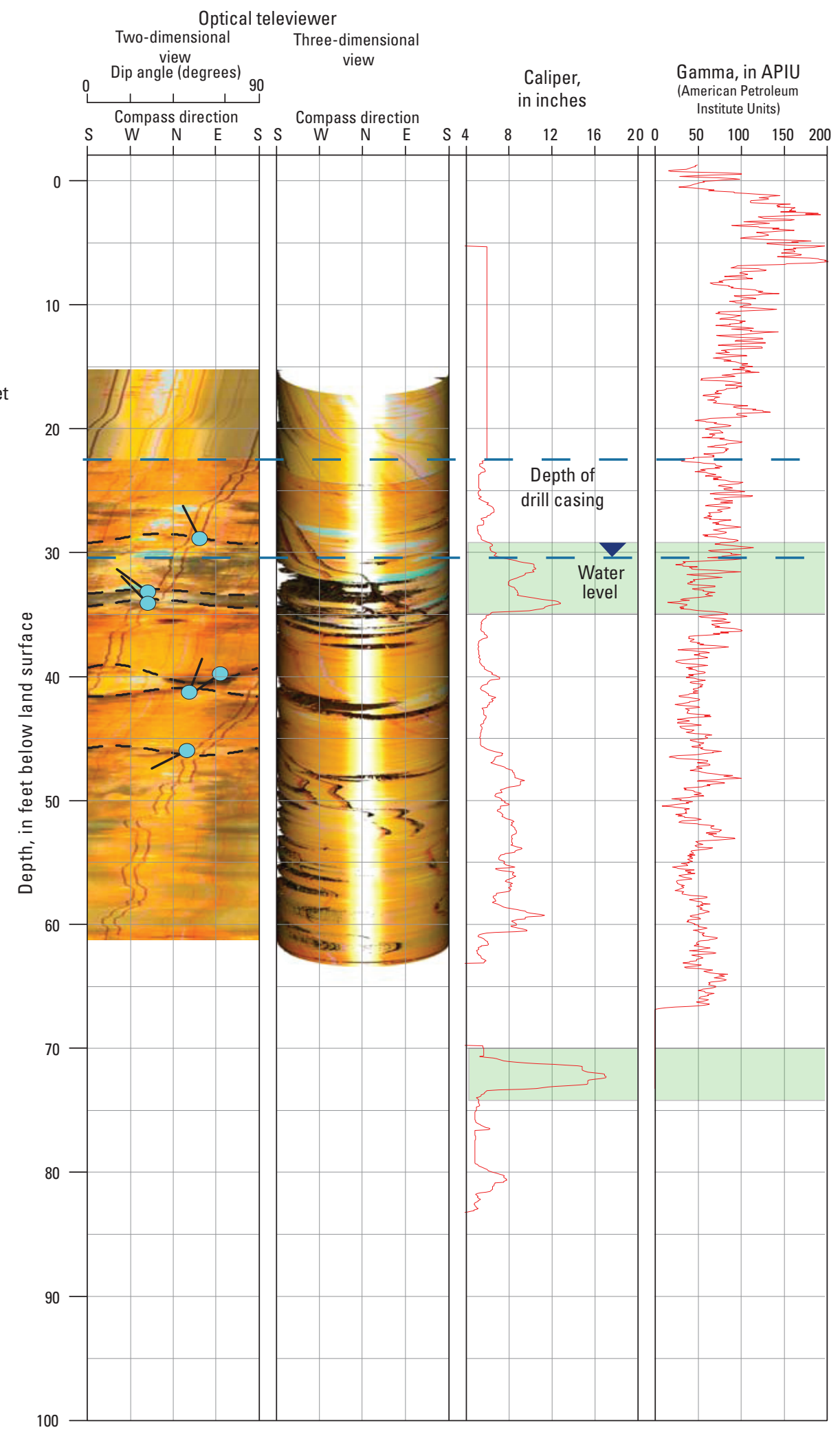

Figure A-6. Borehole geophysical logs and flowmeter data for borehole JW14 near Jim Woodruff Lock and Dam, Lake Seminole, Jackson County, Florida. 


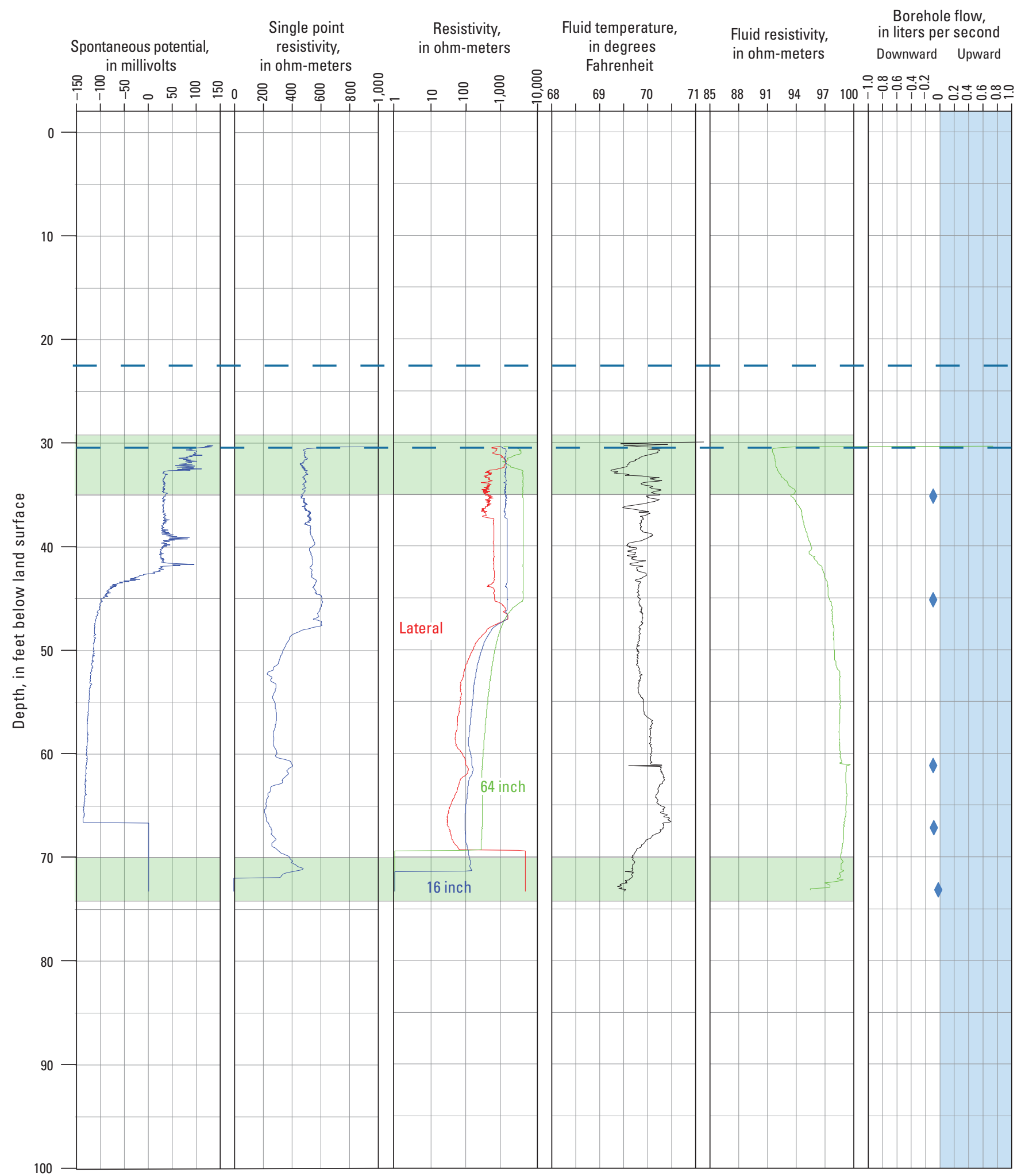

Figure A-6. Borehole geophysical logs and flowmeter data for borehole JW14 near Jim Woodruff Lock and Dam, Lake Seminole, Jackson County, Florida._Continued 
Borehole identifier: JW16

Land-surface altitude,

in feet NAVD88: 85.0

Latitude (NAD83): 304227.6

Longitude (NAD83): 0845214.6

Date logged: 4/29/2011

Borehole deviation: less than 1 foot

All depths in feet

Depth to groundwater: 26.01

Drilled depth: 84

Measured depth: 66.1

Casing depth: None

Casing diameter (inches): None

Structural measurements

$\begin{array}{llll}\text { Depth } & \text { DipAzm } & \text { DipAng } & \text { Type } \\ 25.7 & 169.75 & 65.76 & \mathrm{~F} \\ 27.7 & 329.74 & 56.81 & \mathrm{~F} \\ 29.6 & 190.01 & 65.08 & \mathrm{~F} \\ 30.4 & 67.99 & 56.45 & \mathrm{~F} \\ 34.2 & 150.35 & 70.83 & \mathrm{~F} \\ 35.8 & 58.51 & 61.05 & \mathrm{~F} \\ 38.3 & 67.3 & 17.92 & \mathrm{~B} \\ 43.2 & 349.43 & 50.69 & \mathrm{~F} \\ 50.4 & 218.46 & 0.96 & \mathrm{~B} \\ 57 & 352.81 & 52.65 & \mathrm{~F} \\ 60 & 227.15 & 65.36 & \mathrm{~F} \\ 62.7 & 210.7 & 64.8 & \mathrm{~F}\end{array}$

Type: $F$, minor fracture; $B$, bedding plane

Remarks: None.

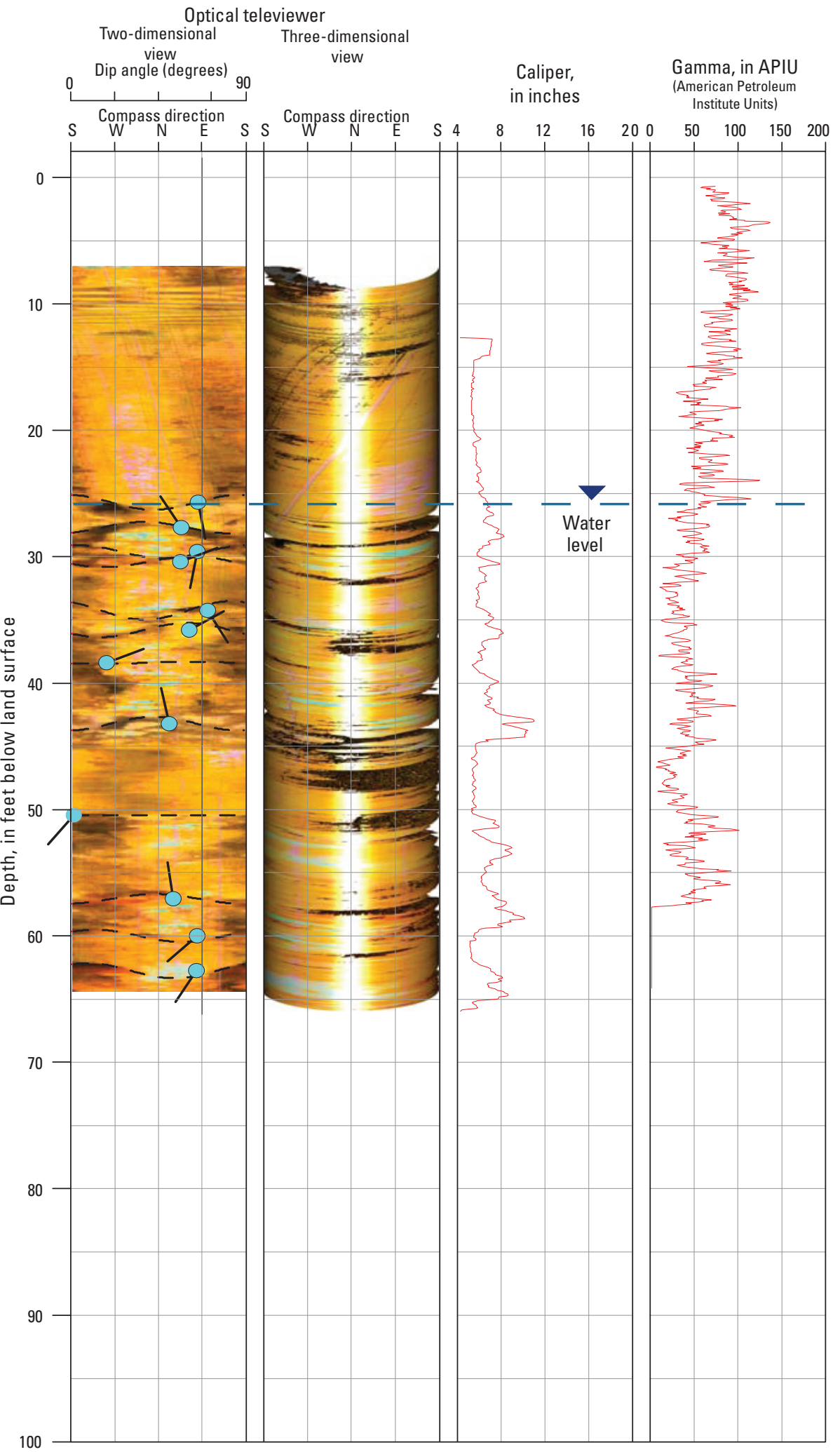

Figure A-7. Borehole geophysical logs and flowmeter data for borehole JW16 near Jim Woodruff Lock and Dam, Lake Seminole, Jackson County, Florida. 


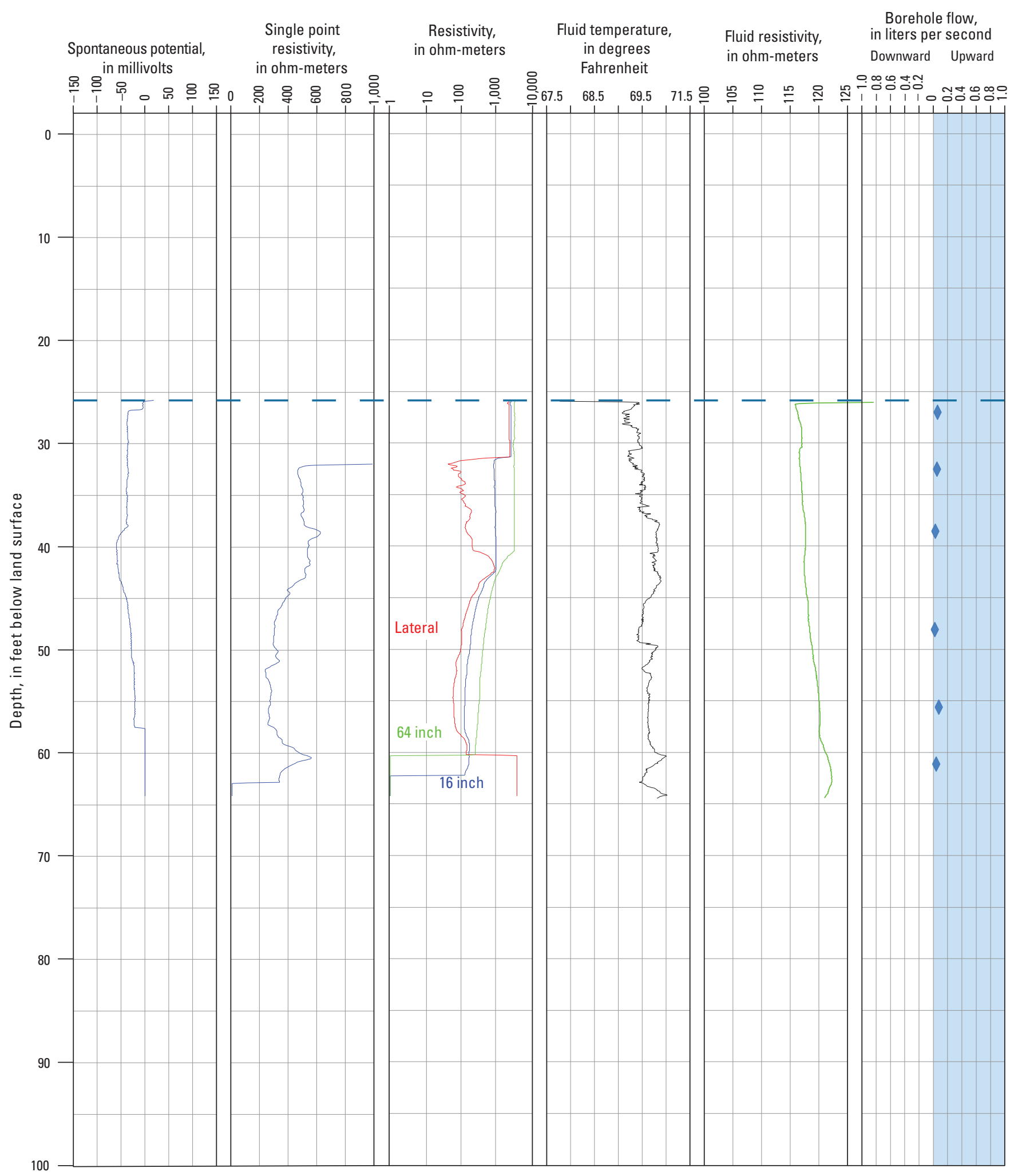

Figure A-7. Borehole geophysical logs and flowmeter data for borehole JW16 near Jim Woodruff Lock and Dam, Lake Seminole, Jackson County, Florida.-Continued 
Borehole identifier: JW17

Land-surface altitude, in feet NAVD88: 84.0

Latitude (NAD83): 304227.3

Longitude (NAD83): 0845214.2

Date logged: 4/27/2011

Borehole deviation: Northwest 4.53 feet

All depths in feet

Depth to groundwater: 23.08

Drilled depth: 104

Measured depth: 104

Casing depth: 27

Casing diameter (inches): 6

Structural measurements

$\begin{array}{llll}\text { Depth } & \text { DipAzm } & \text { DipAng } & \text { Type } \\ 26.4 & 120.84 & 46.37 & \mathrm{~F} \\ 37.1 & 324.64 & 81.99 & \mathrm{~F} \\ 52.4 & 52.57 & 58.38 & \mathrm{C} \\ 55.3 & 40.08 & 64.9 & \mathrm{C} \\ 73.2 & 114.51 & 63.44 & \mathrm{~F}\end{array}$

Type: $\mathrm{F}$, minor fracture; $\mathrm{C}$, cavernous zone

Remarks: Major cavern zone likely at 52.4-55.3 feet, however, caliper log does not indicate large diameter. This may result from bridging of rock debris in the cavern zone.

\section{Major cavern zone- Maximum diameter exceeds 12 inches}

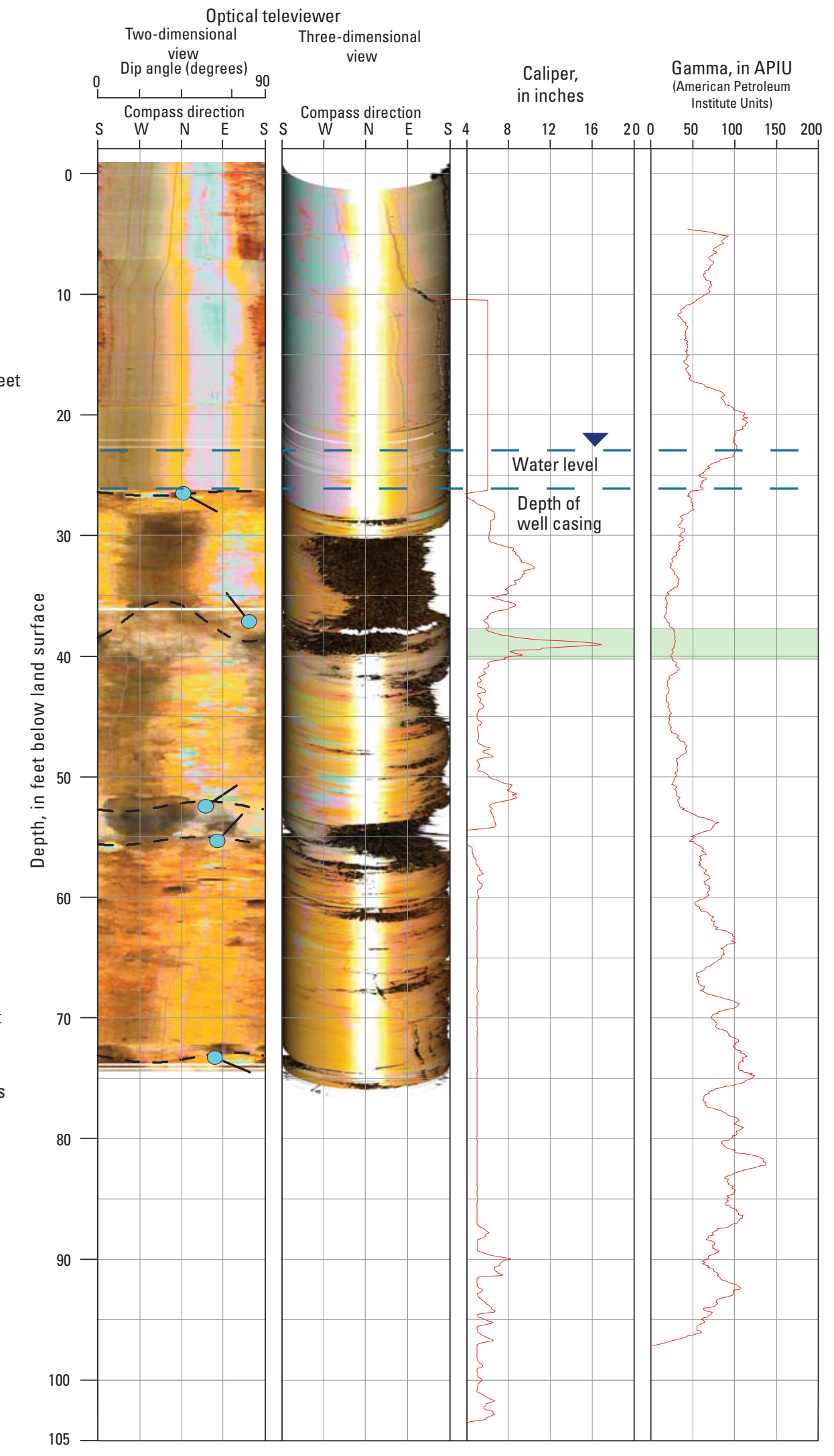

Figure A-8. Borehole geophysical logs and flowmeter data for borehole JW17 near Jim Woodruff Lock and Dam, Lake Seminole, Jackson County, Florida. 


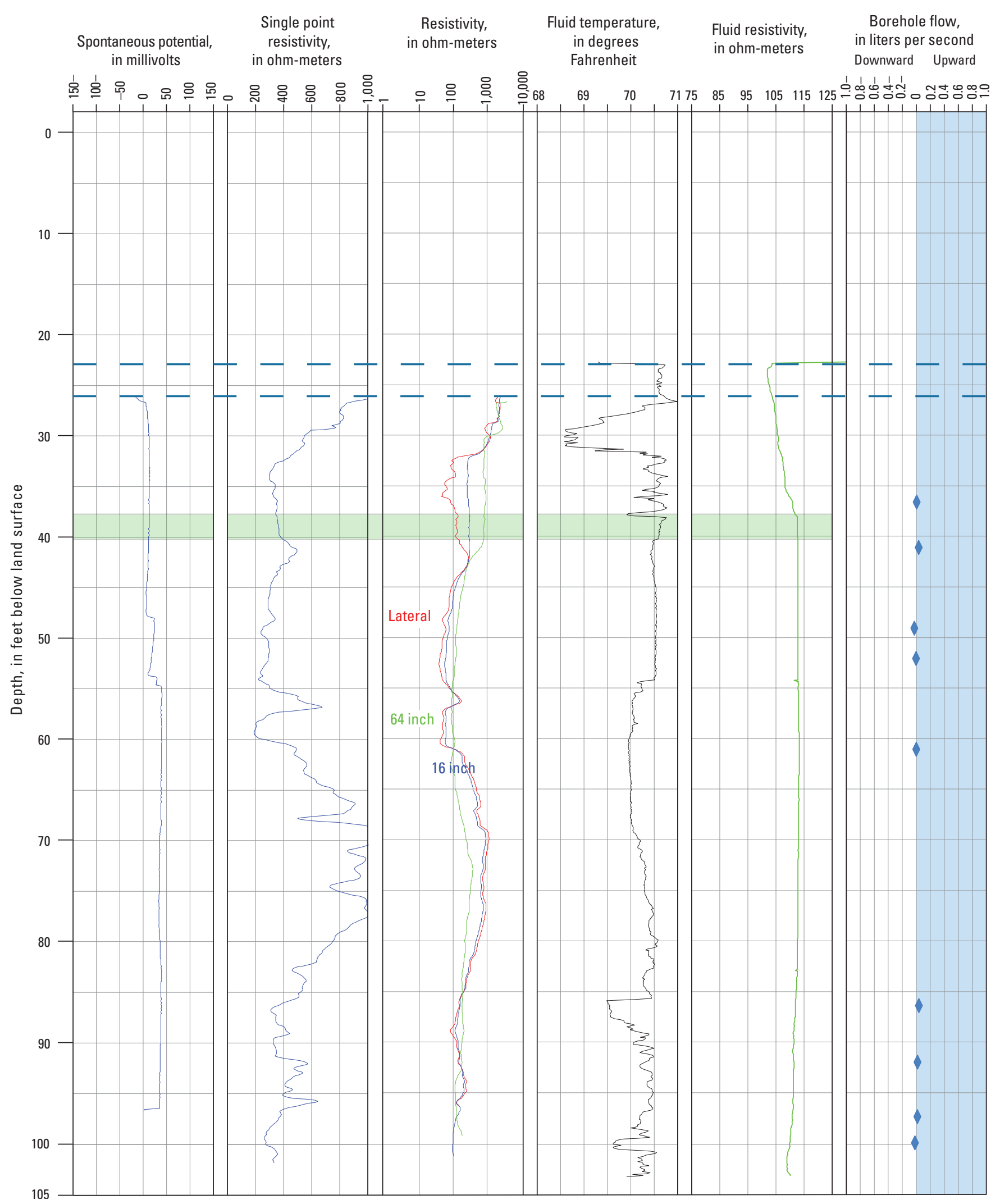

Figure A-8. Borehole geophysical logs and flowmeter data for borehole JW17 near Jim Woodruff Lock and Dam, Lake Seminole, Jackson County, Florida.-Continued 
Manuscript approved for publication, September 20, 2011

Edited by Kay E. (Hedrick) Naugle

Illustrations by Bonnie J. Turcott

Layout by Caryl J. Wipperfurth

For more information concerning the research in this report, contact USGS Georgia Water Science Center

3039 Amwiler Road

Atlanta, Georgia 30360

telephone: $770-903-9100$

http://ga.water.usgs.gov 
